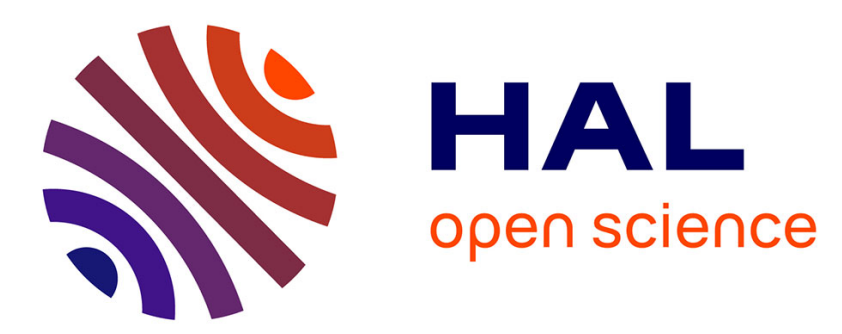

\title{
Cluster Policies and Firm Selection: Evidence from France
}

Lionel Fontagné, Pamina Koenig, Florian Mayneris, Sandra Poncet

\section{To cite this version:}

Lionel Fontagné, Pamina Koenig, Florian Mayneris, Sandra Poncet. Cluster Policies and Firm Selection: Evidence from France. Journal of Regional Science, 2013, 53 (5), pp.897-922. 10.1111/jors.12050 . hal-00975554

\section{HAL Id: hal-00975554 https://hal.science/hal-00975554}

Submitted on 8 Apr 2014

HAL is a multi-disciplinary open access archive for the deposit and dissemination of scientific research documents, whether they are published or not. The documents may come from teaching and research institutions in France or abroad, or from public or private research centers.
L'archive ouverte pluridisciplinaire HAL, est destinée au dépôt et à la diffusion de documents scientifiques de niveau recherche, publiés ou non, émanant des établissements d'enseignement et de recherche français ou étrangers, des laboratoires publics ou privés. 


\title{
Cluster policies and firm selection: Evidence from France*
}

\author{
Lionel Fontagnéł Pamina Koenig; Florian Mayneris ${ }^{\S}$ and Sandra Poncet ${ }^{\llbracket}$
}

October 26, 2012

\begin{abstract}
In this paper, we shed light on the selection of the beneficiaries from the French competitiveness cluster policy which was launched in 2005 and extended to 2012 . We disentangle the selection and self-selection effects, as emphasized in the theoretical literature on regional and industrial policy. Our main conclusion is that winners were (self-)selected at both steps of the procedure, and that this holds for the three cluster types: "worldwide clusters", "potentially worldwide clusters" and "national clusters". We thus provide a methodology which allows us to contrast the effective outcomes of the selection process and the official objectives of cluster policies in terms of targeting, and which thus helps in their econometric evaluation.
\end{abstract}

JEL Codes: F1, F14, R58.

Keywords: Competitiveness, clusters, international trade, firm selection.

\section{Introduction}

Cluster initiatives are popular among policy makers, based on externality and localized growth arguments in the economic literature, suggesting that subsidies for local networks

${ }^{*}$ We thank Matthieu Crozet for helpful advice. We also thank three anonymous referees and Steven Brakman, the editor, for very useful comments. Funding Acknowledgement: This paper is produced as part of the project European Firms in a Global Economy: Internal policies for external competitiveness (EFIGE), a Collaborative Project funded by the European Commission's Seventh Research Framework Programme, Contract number 225551. We are grateful to the French administration for providing us with the list of firms in the selected clusters.

†Paris School of Economics (Université de Paris 1) and CEPII; E-mail: lionel.fontagne@univ-paris1.fr

$\ddagger$ University of Rouen \& Paris School of Economics; E-mail: koenig@pse.ens.fr

§IRES, CORE, Université catholique de Louvain; E-mail: florian.mayneris@uclouvain.be

"Paris School of Economics (Université de Paris 1) and CEPII; E-mail: sandra.poncet@cepii.fr 
of firms could be useful 1 Clustering may encourage the mutualization of some production costs and the diffusion of knowledge: Rosenthal and Strange (2004) survey the empirical literature on agglomeration externalities and confirm the economic gains linked to the spatial concentration of production..$^{2}$

In parallel with the link between public policy and the academic literature, cluster policies are increasingly being econometrically evaluated: Falck et al. (2010) use firmlevel data to evaluate a cluster policy introduced in Bavaria in 1999, Engel et al. (2011) focus on two German cluster initiatives in the biotechnology industry, Nishimura and Okamuro (2011) consider a Japanese cluster policy, and Viladecans-Marsal and ArauzoCarod (2011) analyze a cluster policy in the district of Barcelona. While this work has provided important information which can help with future policy, one common feature of this evaluation literature is that little is said about the selection of firms into subsidized clusters.

Analyzing the outcome of the selection of beneficiaries is important for at least three reasons. First, by assessing which locations and firms have been subsidized, we can compare the "revealed" objectives of the policy to the "official" ones that were announced with the implementation of the policy. Second, when the "revealed" and "official" objectives of the policy are not the same, the careful assessment of the stage of the selection process at which the discrepancy came about may help to improve policy design. This contributes to the debate over the political economy of firm and region targeting. A number of papers have emphasized that traditional industrial policies very often pick "losers", i.e. firms in declining sectors or areas (Beason and Weinstein, 1996; Martin et al., 2011b); it is however still unclear whether this reflects the preferences of policy makers (Corden, 1974; Krueger, 1990), the capture of governments by particular firms (Baldwin and Robert-Nicoud, 2007) or the design of the policies themselves (Baldwin and Okubo, 2006). Finally, the analysis of the selection process aids the econometric evaluation of the policy, by shedding light

\footnotetext{
${ }^{1}$ Official documents accompanying cluster initiatives such as the competitiveness clusters in France, the Kompetenznetze in Germany or the clusters in the Spanish Basque country, explicitly or implicitly refer to Marshallian-type externalities. See the official websites http://competitivite.gouv.fr/, http://www.kompetenznetze.de/the-initiative and http://www.industria.ejgv.euskadi.net/r44de0006/es/contenidos/noticia/clusters_sectoriales_09/es_clusters/clusters.html

${ }^{2}$ However, the literature also suggests that in general, there are only few gains to be expected from further spatial concentration. For example, Martin et al. (2011a) find that firms seem to have already internalized most of the productivity gains from agglomeration in their location choices, bringing into question any economic gains expected from policies aimed at increasing spatial concentration.
} 
on the characteristics that differentiate recipient from non-recipient firms and regions. Information about selection is crucial to identify the control groups that are necessary for policy evaluation.

In this paper, we analyze selection process in the French competitiveness clusters policy. This was launched by the French government in 2005 for a three-year period, later extended to 2009-2012. This policy is based on calls for tender leading to financial subsidies for innovative projects which are managed collectively by firms, research departments and universities. A first call was issued in 2004 to select the competitiveness clusters, i.e. locations specialized in some particular activity (the aerospace industry in Toulouse, microelectronics in Grenoble etc.) in which firms were eligible for directly-targeted R\&D subsidies. These subsidies for collective R\&D projects were themselves distributed following calls for tender which were regularly issued after the selection of the competitiveness clusters. In that sense, the French competitiveness clusters policy can be said to be an archetypal modern industrial policy, favoring a "bottom-up" approach: projects emanate from the firms and the regions, within the framework defined by the calls for tender. This is opposed to a "top-down" approach, whereby the public authorities decide everything. Compared to the first French cluster policy starting in 1998, and other experiences in Europe (see the literature review below), the current competitiveness clusters scheme is ambitious and fairly costly ( 1.5 billion Euros in each three-year phase): the 500 million Euros per year represents around $5.5 \%$ of the French national budget allocated to universities and research.

Our work builds on that in Martin et al. (2011b), which is the only paper to document selection into a cluster policy using French data. Firm-level data is used to analyze quantitatively the effects of the first French cluster policy at the end of the 1990's, the Local Productive Systems policy. A difference-in-difference model is applied to a matched sample of firms. The results of their first-stage equation show that subsidized firms were found in regions that lagged behind and in declining sectors. This shows that, despite the official announcement, this policy did not mark any radical shift in the conception of French regional policy.

We here focus on selection in the current French competitiveness clusters policy. This policy is of interest since the pool of beneficiaries reflects the outcome of both selection and 
self-selection. In July 2005, the government chose the subsidized competitiveness clusters from the 105 applications received. Firms then joined the competitiveness clusters by becoming members of the organization managing the cluster (which was generally an association). The first step hence selects industry-area pairs revealing the government's selection among applicants, while firms then self-select into the chosen competitiveness clusters. For example, a biotech cluster was selected in the vicinity of Lyon ("Lyon Biopole"). 28 firms then became active members of this cluster in 2006. Member firms could apply for R\&D tenders specifically oriented to labeled competitiveness clusters.

We follow closely the selection procedure of the French competitiveness clusters in order to highlight the different types of selection at work. We first ask how the location of clusters was chosen: Is there any evidence, within a given sector, that selected locations contain more efficient firms on average? Not all of the firms in a selected sector-location pair became members of the organization managing the cluster and applied for subsidies. We thus focus in a second step on the selection of firms within the subsidized clusters, and check whether cluster-member firms are more efficient than other firms in the same sectorlocation. This second stage will help us to understand the kind of self-selection generated by the design of the competitiveness clusters. Last, we see whether cluster-member firms show an export premium once their individual characteristics (e.g. productivity) have been controlled for. Any such premium would suggest that firm geographical clustering adds to the firm-specific competitive advantage.

The goal of the French cluster policy is to promote innovation through increased collaborations between firms, private research centres and universities, and to strengthen the competitiveness of French products on international markets. Firm-level efficiency and competitiveness have many interdependent dimensions. As this policy aims to promote competitiveness in a context of increasing international competition, we choose to focus on firm export performance and productivity before they received public support. Information on alternative direct firm-level measures of innovation ( $R \& D$ expenditures, patents etc.) is not exhaustive in France, and the coverage of firm-level export data is much better. We also believe that productivity and export performance capture differences between firms regarding innovation, as a number of pieces of work have shown that innovation, productivity and exports are closely related. Aw et al. (2011) use Taiwanese 
data to show that an expansion of the export market increases both the probability of exporting and $\mathrm{R} \& \mathrm{D}$ investment, generating within-plant productivity gains. Cassiman and Golovko (2011) find in Spanish data that the positive association between productivity and exports can be largely explained by firms' earlier innovation decisions. Iacovone and Javorcik (2012) show that Mexican firms increase the quality of their products before entering export markets, and Van Beveren and Vandenbussche (2010) use Belgian data to show that firms self-select into innovation activities, anticipating entry into foreign markets.

Three categories of clusters were defined by the French government in 2005, reflecting differences in terms of expected scope. "Worldwide clusters" are at the top of this ranking, followed by "potentially worldwide clusters" and "national clusters". Our main conclusion is that the two-step selection procedure led the public authorities to favor better-performing places and firms in a given sector. Using 2004 export performance as an efficiency measure, we find that in a given sector, public authorities selected locations with better-performing firms on average, compared to firms in the same sector located in other regions. Moreover, within a given chosen sector-location, the firms that actively joined (self-selected in) the competitiveness cluster have better export performance and higher productivity than those that did not. Our results reassuringly show that the three cluster categories group together different types of firms: locations and firms in "worldwide competitiveness clusters" have better performance than those in "potentially worldwide clusters", and the latter perform better than those in "national clusters". We underline that "picking winners" holds especially for "national" clusters, where firm heterogeneity is the greatest. We only observe an export premium, after controlling for individual characteristics such as size and productivity, for firms in national clusters.

This paper does not aim to be normative. It is actually difficult to know how to target cluster policies. Industrial policies are criticized by economists on the grounds that they often help declining sectors or firms, impeding or delaying the reallocations of activities that would be beneficial for aggregate productivity (see Criscuolo et al., 2012). However, this does not necessarily mean that public authorities should help always "winners", i.e. regions or firms that already perform well, since it is not obvious that they will be more affected in terms of performance by public intervention than regions or firms which are 
lagging. In this paper, we rather try to provide a methodology that could be reproduced for the analysis of selection in industrial policies that are based on a two-step procedure, such as the French competitiveness clusters considered here.

The remainder of the paper is organized as follows. Section 2 briefly discusses the existing literature, and the data are described in Section 3. Section 4 looks at whether the selected clusters exhibit on average an export premium in their sector. Section 5 then asks whether the firms selected to join the clusters have an export premium, but without controlling for their individual characteristics. These individual characteristics are controlled for in Section 6. Last, Section 7 concludes.

\section{Literature}

There are two theoretical elements in the discussion of policies subsidizing firms and regions. The main question asked by economists addresses the economic mechanisms underlying the clustering of economic activity: this is briefly reviewed in the first part of this section. The second element, which is linked to the development from traditional industrial and regional policy to modern cluster policy, is targeting. There are three ways of addressing this issue: How is the selection? How could it be? And how should it be? We will concentrate on the positive aspect of selection, i.e. the first question, although we briefly mention normative aspects in the paper's introduction. We thus review below the positive results regarding selection in different theoretical frameworks.

\subsection{Clusters and cluster policies}

Policy makers seem to be very enthusiastic about cluster policies. A great many initiatives have been taken around the world to promote (and subsidize) clusters. It is not only countries (France, Brazil, Belgium, South-Korea, Japan, UK etc.) which have promoted clusters, but also regions (Bavaria, the Spanish Basque country, Catalonia, Wallonia etc.). The Global Cluster Initiative Survey 2005 suggests that over 1,400 cluster initiatives were in place around the world in 2005, 3 most of which started at the end of the 1990s. These include both very ambitious and more modest policies. The "BioRegio"

\footnotetext{
${ }^{3}$ For a detailed overview, see Solvell et al. (2003).
} 
(750 million Euros) and "BioProfile" (150 million Euros) programs in Germany and the "Production Industries in London" initiative (15 million Euros over 2006-2008) are much less expensive, for example, than the French competitiveness cluster policy.

Arguments for subsidizing local networks of firms mainly stem from the management literature. Economists have a more nuanced point of view here, as summarized in Duranton et al. (2011). The management literature largely refers to the work of Michael Porter $(1998,2000)$, which provides a modern definition of agglomeration, based on a theoretical tool, the "competitive diamond". This explains local competitive advantage by the relationships linking "demand conditions", "factor (supply) conditions", "related and supporting industries" and the "context for firm strategy and rivalry". Martin and Sunley (2003) however note that this concept of clusters is too vague to be helpful. As the causal relationship between the different elements of the diamond is unclear, it is difficult to know, using this theoretical tool, which exact mechanisms drive local growth, and so to determine the relevant cluster policies. In addition, Duranton et al. (2011) and Duranton (2011) both argue that important elements, such as labor mobility or land markets, are crucial for the analysis of cluster dynamics but are absent from this representation.

Porter (2000) considers that any intervention which stimulates one element of the diamond is good, since it will feed back on all of the other elements. Porter cites, amongst others, subsidies aiming at increasing the cluster size, the creation of specialized education programs, and transport infrastructure. "Place-based" policies are however the subject of considerable controversy in the literature (see Barca et al., 2012). Duranton et al. (2010) disagree with Porter and note that cluster policies should be justified by the existence of market failures or externalities which would not be internalized by economic agents without some public intervention. As such, acknowledging the benefits from clusters does not suffice to make the case for cluster policies. Duranton et al. (2010) also emphasize that cluster policies are characterized by sizeable information asymmetries which could undermine their efficiency. Existing work generally finds at most a modest and short-run positive impact of cluster policies (see Engel et al., 2011; Martin et al. , 2011b; Nishimura and Okamuro, 2011; Viladecans-Marsal and Arauzo-Carod, 2011).

In the French case, the arguments for clusters are reinforced by the country's poor export performance: the French trade balance has been in secular decline since the end of 
the 1990s and negative since 2005. Increasing international competition was mentioned as one motivation for the competitiveness cluster policy, in order to improve French firms' export performance. $]^{4}$ In particular, the lack of cooperation between universities, research centers and industrial firms, and the insufficient number of medium-sized exporters, have often been evoked as the market failures behind this poor export performance, notably with respect to their German counterparts. Clustering could help in this respect.5 On the one hand, it could encourage innovation and quality upgrading, thus increasing the competitiveness of French products; on the other hand, it could help to reduce the fixed export costs emphasized in the new trade theory (Melitz, 2003). While the bulk of these costs are specific to the firm, some may be shared, in particular when it comes to collecting information on remote or uneasy markets. The results in Koenig et al. (2010 and 2011) confirm the existence of such local export spillovers in France, which are stronger for more difficult to access markets 6

\subsection{The political economy of industrial policies}

The positive literature on selection focuses largely on the political economy of industrial and regional policy. The kind of selection we can expect from industrial policy is ambiguous. The empirical literature shows that industrial policy often targets losers, i.e. declining sectors or weaker regions (see Beason and Weinstein, 1996 and Martin et al., 2011b). The theoretical literature has proposed a number of explanations of governments' apparent difficulty to pick winners.

A first strand of the literature focuses on the social planner's welfare function. Corden (1974) suggests that revenue losses are assigned a higher weight in the social planners' welfare function than are revenue gains. Krueger (1990) justifies this alleged bias of governments in favor of losers by individual psychological traits: there is an "identity bias", so that people care more about people they know than about others; in that sense, it is easier to feel empathy for people who lose their jobs, as they can be clearly identified,

\footnotetext{
${ }^{4}$ See http://competitivite.gouv.fr/la-mise-en-oeuvre-de-la-politique-des-poles-depuis-2005/les-enjeuxde-la-politique-des-poles-477.html.

${ }^{5}$ See Artus and Fontagné (2006).

${ }^{6}$ Difficulty here is measured as the degree of risk of the destination market (using the ICRG index) or as the cost associated with exporting to this particular destination (using the World Bank "Doing Business" database).
} 
than for the potential beneficiaries of future jobs, who are unknown.

Baldwin and Robert-Nicoud (2007) propose an alternative model, in which it is not the governments that pick losers but rather the losers who capture industrial policies. They show that in the presence of sunk entry costs, the rents created by lobbying are higher in declining industries, due to lower competition there as compared to expanding industries. Firms operating in declining industries thus have greater incentives to lobby for subsidies.

Recent work has introduced firm heterogeneity in lobbying models in order to understand which firms, within a sector, have the greatest incentives to lobby. Bombardini (2008) in particular shows that in the presence of fixed costs linked to lobbying activities, larger firms will be more likely to engage in lobbying, and finds empirical support for her model in US data. This literature contrasts with the "picking losers" analyses: as lobbying is costly, it does not necessarily follow that only poorly-performing firms will benefit from protection and industrial policy. This analysis seems particularly relevant in the case of the French competitiveness clusters. Participating can be profitable, but it is also costly. In order to obtain R\&D subsidies, firms in clusters must apply to calls for tender which are specifically dedicated to them. There are thus application forms to fill in, and administrative monitoring to undertake in the case of success, which could produce self-selection by larger or better-performing firms in competitiveness clusters.

The type of incentives provided by regional or industrial policy might also shape the pool of beneficiaries: Baldwin and Okubo (2006) use a new economic geography model with heterogeneous firms to show for example that, starting from a core-periphery situation, a per-firm subsidy aimed at encouraging production in the periphery tends to attract the least-efficient firms. These are the firms that have the least to lose from leaving the core region, since they benefit the least from agglomeration economies and suffer the most from the tougher competition there. Conversely, Baldwin and Okubo (2009) show that if incentives take the form of lower taxes, big firms, who pay more tax in absolute terms, may have a greater incentive to move. In the same vein, Okubo (2012) shows that a subsidy proportional to profits can induce the relocation of high-productivity firms to the periphery. These results can shed light on the different outcomes from (self)-selection in the two French cluster policies. The Local Productive Systems, evaluated by Martin 
et al. (2011b), consisted of a small one-shot subsidy aimed at financing any collaborative projects between firms. The competitiveness clusters policy is very different, since most of the incentives consist of R\&D subsidies for projects involving several firms and labs, and the firms engaged in R\&D activities are generally more productive.

In the following, we do not deal with the exact mechanisms that drive selection into competitiveness clusters, as they are unobserved. We thus do not directly address the questions of lobbying, policy-makers' preferences or connections between policy-makers and cluster managers etc. We instead focus on the outcome of selection, taking advantage of the two-step procedure to uncover both selection and self-selection effects. The literature cited above is however a useful background to guide the interpretation of the results we obtain.

\section{$3 \quad$ Data and descriptive statistics}

\subsection{Data}

We appeal to three main data sources. First, we rely on individual exports as recorded by French customs. Each year, the data list the exports of all firms located in France 7 at the 8-digit level of the CN8 product classification, comprising over 10,000 different product lines ${ }^{8}$ Our analysis evaluates the performance of firms prior to the implementation of the competitiveness clusters policy in 2005, using trade data for the year 2004. In most estimations, we capture firm efficiency by the value and volume of exports at the firm-level aggregated over all products and destinations.

The second data source is the Annual Business Surveys (ABS) $)^{9}$, which provide firmlevel balance sheet data such as employment, capital, and value-added etc. We use ABS data restricted to manufacturing firms, and thus do not cover services and agrifood industries. These data give information on firm productivity. This dataset is however restricted

\footnotetext{
${ }^{7}$ More precisely, Customs record exports at the company level. Companies may belong to groups. We will however use the term "firms" for the sake of simplicity. We ensure that our results are robust when controlling for ownership.

${ }^{8} \mathrm{CN} 8$ stands for Combined Nomenclature 8-digit. Within the EU, French customs collect information on the product exported by firms when the annual cumulated value of all shipments of a firm (in the previous year) is above 100,000 Euros from 2001 onwards. Regarding extra-EU exports, all shipments above 1,000 Euros are reported.

${ }^{9}$ Which are called in French the "Enquêtes Annuelles d'Entreprise" (EAE).
} 
to firms with over 20 employees.

Last, we need to know which firm belongs to which cluster. The French Ministry of Finance provided us the list of the 4,552 firm members of competitiveness clusters in 2006. These firms had not necessarily received R\&D subsidies at that time; they were only eligible, as members of competitiveness clusters, to apply to national R\&D tenders specifically aimed at competitiveness cluster firms. This dataset also contains information on the number of employees by firm.

The process of matching firms in France is straightforward, as each firm has a unique identifier (SIREN) that is the same across the different datasets. The combination of the three datasets nevertheless raises a number of issues. First, the ABS contain both single and multi-plant firms. In the latter case, the total employment in the ABS is that for the firm as a whole. Second, not all firms export goods: some may export services and some may not export at all, while exports of services are not recorded by Customs. Last, small exporters, with fewer than 20 employees, are not covered by the ABS, even if they export goods. Out of the 111,960 exporting firms in the Customs dataset for the year 2004, 13,587 appear in the manufacturing ABS, of which 1,010 belong to at least one cluster. Starting from a total of 2,242 exporters in all the clusters, these restrictions imply the loss of half of the exporters identified as belonging to a cluster. We thus proceed with different samples corresponding to different combinations of the restrictions. We first use the whole set of firms. Then, in order to control for productivity and size, we restrict the sample to the firms with more than 20 employees (which hence appear in the ABS); we do however check that results are not affected by the change in the estimation sample. Finally, we make sure that our results continue to hold when we control for the number of plants, and thus restrict the sample to single-plant firms.

For each firm and year, we compute the number of exported products and the number of destination countries. We use the CEPII geographic database ${ }^{10}$ to obtain the distance between France and each destination country, and compute the weighted average distance of the firm's destination countries (weighting the distance to each country by the share of the country in the firm's total exports).

\footnotetext{
${ }^{10}$ The dataset "geo cepii" is available at http://www.cepii.fr/francgraph/bdd/distances.htm.
} 
Table 1: Share of competitiveness clusters in French export activity (firms)

\begin{tabular}{|l|cccccc||}
\hline \hline Share in total... & $\begin{array}{c}\text { Exporting firms } \\
\text { in clusters }\end{array}$ & $\geq 99$ p. & $90-99$ p. & $75-90$ p. & $50-75$ p. & $1-50$ p. \\
\hline No. of exporters & 2.00 & 21.56 & 6.64 & 2.94 & 1.54 & 0.71 \\
export value & 27.35 & 35.59 & 9.05 & 3.21 & 1.74 & 0.79 \\
\hline \hline
\end{tabular}

Note: Firms are ordered decreasingly by their individual export value. The table contains the shares of different percentiles of the distribution of individual export value in total French exports. The values in the first (second) row correspond to the percentage of firms engaged in clusters in the column category in the total number (export value) of French exporters.

\subsection{Some descriptive statistics}

Table (1) illustrates the selection of firms into competitiveness clusters. Based on 2004 trade data, we find that only $2 \%$ of all French exporters are found in competitiveness clusters. However, the exporting firms in clusters represent $27.35 \%$ of total French exports, suggesting that they are bigger exporters than are non-cluster firms. Mayer and Ottaviano (2007) have shown that exporting is a matter of "superstars". They find that the top one percent of French exporters account for $44 \%$ of total exports. Many of those "superstars" are likely involved in French competitiveness clusters. This selection also appears when we run the analysis for different size categories: $21.6 \%$ of firms in the top one percent of exporters were selected into competitiveness clusters; they represent $35.6 \%$ of the total value of exports in this category of exporters. On the contrary, only $0.71 \%$ of the top half of exporters in terms of size were selected into the competitiveness clusters (representing $0.79 \%$ of total exports in this category). The LIFI database, available at INSEE, the French National Institute for Statistics, indicates the ownership of individual firms and thus allows us to establish groups of firms. We ask how industrial groups are represented in clusters based on the share of groups with at least one firm engaged in a cluster. The concentration of observations remains striking when we control for ownership: Table (2) displays the same information as Table (1), with members of competitiveness clusters now being represented through the group to which they belong. This shows that groups involved in clusters account for $10.94 \%$ of French exporting groups, but for $75.01 \%$ of their exports. In the first percentile of groups ordered according to their exported value, these percentages are respectively $86 \%$ and $93.51 \%$.

As noted above, clusters were grouped by public authorities into three categories, 
Table 2: Share of Competitiveness Clusters in French export activity (groups)

\begin{tabular}{||l|cccccc||}
\hline \hline Share in total... & $\begin{array}{c}\text { Exporting groups } \\
\text { in clusters }\end{array}$ & $\geq 99$ p. & $90-99$ p. & $75-90$ p. & $50-75$ p. & $1-50$ p. \\
\hline No. of exporters & 10.94 & 86 & 33.11 & 18.09 & 10.02 & 3.79 \\
export value & 75.01 & 93.51 & 41.46 & 19.70 & 10.56 & 5.00 \\
\hline \hline
\end{tabular}

Note: Groups are ordered decreasingly by their export value. The table contains the shares of different percentiles of the distribution of group-level export value in total exports of French groups. The values in the first (second) row correspond to the percentage of groups engaged in clusters in the column category in the total number (export value) of French exporting groups.

according to their alleged performance: category 1 refers to "worldwide competitiveness clusters", category 2 to "potentially worldwide competitiveness clusters" and category 3 to "national competitiveness clusters". The full list of clusters in 2006, by category, is provided in Appendix Table A-1]. There were on average 114 firms in category 1 clusters in 2006, with an average size of 2,500 employees (these were hence large firms). Under half of these firms were direct exporters (the smallest firms may use intermediaries to export, however we can not see this in the database). "Lyon biopole", the biotech cluster mentioned above, is the smallest cluster in this first category, with 28 firms involved, 14 of which export goods. In the category 2 clusters, firms are of similar size (2,400 employees on average), and the clusters are smaller (90 firms on average). Around $40 \%$ of the firms here are exporters and the smallest cluster, "Innovations thérapeutiques", comprises 29 firms (involved in the health sector). The third category of clusters is very heterogeneous. It consists of small clusters oriented toward innovation (such as "innovative materials (MIPI)", 18 firms) as well as large clusters for which the innovative orientation is less obvious (427 firms in the meat sector "Viandes et produits carnés"). As such, average firm size is not very informative in this latter group. The export orientation of "national competitiveness clusters" turns out to be greater than that of the "potentially worldwide competitiveness clusters" and "worldwide competitiveness clusters": the share of exporting firms is respectively $55 \%, 40 \%$ and $47 \%$. This figure is even $100 \%$ and $89 \%$ respectively for the clusters "aquatic products" and "innovative materials (MIPI)".

Overall, competitiveness clusters are fairly outward-oriented, as the share of exporters in the whole population of French firms is only around $4 \%$. When we restrict our attention to firms that are present in the manufacturing ABS (around 25\% of firms involved in 
competitiveness clusters are present in the ABS), this ratio rises further to $90 \%$, which is much higher than the average in the ABS sample (69\% of ABS firms are exporters). Note that some firms, in worldwide clusters in particular, may belong to groups which serve foreign markets by their direct presence, via FDI rather than exports.

\section{Selected sector-location pairs show better performances}

This section focuses on the selection of the sector-location pairs in which firms are eligible for the R\&D subsidies associated with the policy. In November 2004 the French government published a national tender to choose clusters. Out of the 105 applications received, 66 were selected: 6 "worldwide", 10 "potentially worldwide" and 50 "national" clusters. Two types of subsidy are available for the selected clusters: overhead costs and subsidies for R\&D projects. The R\&D subsidies were allocated regularly after 2005 via national tenders specifically set up for the competitiveness clusters members. We evaluate the selection of sector-location pairs using firm data, some of which are in and some out of the selected pairs. We compare performance of the sector-locations benefiting from the policy to that of other pairs in the same sector which were not chosen ${ }^{11}$

We define the locations included in the clusters as all of the administrative départements in which there is at least one firm belonging to a selected cluster (based on the list of members of competitiveness clusters obtained from the Ministry of Industry). Symmetrically, an industry, defined at the 3-digit level of the French Nomenclature of Activities (NAF), is said to be represented in French competitiveness clusters when one cluster member belongs to this industry. Some competitiveness clusters group firms pertaining to several industries and/or several départements. In our data, a competitiveness cluster can thus correspond to several sector-location pairs. Performance is assessed in terms of exports and productivity.

We define the average performance $\bar{y}$ of location $r$ in sector $s$ as follows:

$$
\bar{y}_{s r 2004}=\sum_{i \in I_{s r}} \mathrm{~s}_{i s r 2004} y_{i s r 2004}
$$

\footnotetext{
${ }^{11}$ Only 3,635 sector-location pairs have positive exports out of a potential universe of 8,178 (94 départements times 87 3-digit NAF sectors.). As 12 of the 87 3-digit sectors have no firms selected in a cluster, 259 out of the 3,635 sector-location pairs in the regressions have no cluster-counterfactual.
} 
where $y$ is a performance index, $I_{s r}$ the set of firms $i$ belonging to sector $s$ in location $r$ and $\mathrm{s}_{i s r}$ the share of firm $i$ in total exports originating from sector-location pair $s r$.

The aim of this exercise is to identify any differences between locations with and without competitiveness clusters. We thus compare, within a given sector, the average performance of firms in French départements with the policy to that of firms in départements without it. In the first step of the analysis we thus estimate the following:

$$
\bar{y}_{s r 2004}=\alpha \mathrm{WCC}_{s r}+\beta \mathrm{PWCC}_{s r}+\beta \mathrm{NCC}_{s r}+d_{s}+\epsilon_{s r 2004}
$$

where $\mathrm{WCC}_{s r}, \mathrm{PWCC}_{s r}$ and $\mathrm{NCC}_{s r}$ are dummies for at least one firm in sector $s$ and département $r$ belonging to a Wordwide, Potentially Worldwide or National competitiveness cluster. The variable $\mathrm{d}_{s}$ is a sector dummy (defined at the 3-digit level), ensuring that differences for the different cluster types are measured within industries. The coefficients $\alpha, \beta$ and $\gamma$ reflect the average performance premium of firms in départements where a competitiveness cluster is located, over that of firms in the same sector but located in départements without competitiveness clusters. Given the definition of our explanatory variables, the higher are $\alpha, \beta$ and $\gamma$, the more competitive are the locations where the respective clusters are located. Export performance is measured by a variety of indicators (export value, export volume, number of exported products, number of destination countries, average distance of destination countries, and the unit value of exports) ${ }^{12}$

Again consider Lyon Biopole as an example. Since the policy aims to boost the competitive advantage of French industry, our question is then whether biotech firms located in the "Rhône" département (where Lyon is) are on average better performers than other biotech firms in France. To answer this question, we consider all firms located in the "Rhône" and other French départements which have biotech as their main activity. We expect the performance of the biotech-Rhône pair to be higher than any other biotechlocation pair. We thus look for a locational advantage of Lyon in this sector, i.e. greater efficiency in producing and exporting biotech products.

The results of the estimations are shown in Table (3). We use a cross section for year 2004, which is one year prior to the implementation of the policy. As some sector-location

\footnotetext{
${ }^{12}$ Performance indicators are expressed in Ln terms apart from the number of destinations and the number of products so that the percentage impact can be easily calculated.
} 
Table 3: Competitiveness clusters and département/3-digit industry average performance (Customs + ABS dataset)

\begin{tabular}{||c|ccccccc||}
\hline \hline \multirow{3}{*}{ Model: } & \multicolumn{7}{|c||}{ Dependent Variable: Performance in 2004 } \\
\cline { 2 - 8 } & $\begin{array}{c}\text { Export } \\
\text { value }\end{array}$ & $\begin{array}{c}\text { Export } \\
\text { quantity }\end{array}$ & $\begin{array}{c}\text { Unit } \\
\text { value }\end{array}$ & $\begin{array}{c}\text { Number of } \\
\text { products }\end{array}$ & $\begin{array}{c}\text { Number of } \\
\text { destinations }\end{array}$ & $\begin{array}{l}\text { Weighted } \\
\text { distance }\end{array}$ & TFP \\
\hline Best category: WCC & $1.766^{a}$ & $0.971^{a}$ & $1.520^{a}$ & $19.479^{a}$ & $8.070^{a}$ & $0.228^{a}$ & $0.156^{a}$ \\
& $(0.271)$ & $(0.328)$ & $(0.180)$ & $(5.056)$ & $(1.777)$ & $(0.046)$ & $(0.035)$ \\
Best category: PWCC & $1.202^{a}$ & $1.296^{a}$ & $0.438^{a}$ & $11.596^{b}$ & $6.249^{a}$ & $0.142^{b}$ & $0.079^{a}$ \\
& $(0.233)$ & $(0.253)$ & $(0.133)$ & $(5.573)$ & $(1.994)$ & $(0.063)$ & $(0.029)$ \\
Best category: NCC & $1.407^{a}$ & $1.263^{a}$ & $0.548^{a}$ & $9.591^{a}$ & $5.644^{a}$ & $0.107^{b}$ & $0.080^{a}$ \\
& $(0.118)$ & $(0.164)$ & $(0.083)$ & $(1.863)$ & $(0.951)$ & $(0.042)$ & $(0.016)$ \\
\hline Number of & & & & & & & \\
location-sector pairs & 3635 & 3635 & 3635 & 3635 & 3635 & 3635 & 3635 \\
$\mathrm{R}^{2}$ & 0.056 & 0.032 & 0.043 & 0.040 & 0.032 & 0.005 & 0.010 \\
\hline \hline
\end{tabular}

Note: Performance indicators are in Ln apart from the number of products and the number of destinations. Fixed effects at the 3-digit level are introduced in all columns. Standard errors are clustered at the 3-digit level.

pairs may be included in several clusters, we categorize clusters assuming that "Worldwide" clusters (WCC) are better than "Potentially Worldwide" clusters (PWCC), which are themselves better than "National" clusters (NCC), and identify the "best category". Out of the 3,635 sector-location pairs, 102 are included in at least one "Worldwide" cluster, 89 at least one "Potentially Worldwide" cluster and 382 in at least one "National" cluster as their best category.

The estimated coefficients in the first column of Table (3) show that firms in the three types of clusters do export more than firms in the same 3-digit sector but other départements. This premium is the largest for "Worldwide" clusters. More generally, we observe that the price-quality range of the exported products, the diversification of products, the diversification of markets, and the ability to export to remote markets are greater on average, for a given 3-digit sector, in the selected locations. The coefficient of 1.766 for "Worldwide" clusters regarding export value implies that firms in "Worldwide" clusters export $5.85[\exp (1.766)]$ times more than do firms from the same 3-digit sector but located in other départements.

The last column further shows that average productivity (of a given 3-digit sector) is greater in locations with a cluster. ${ }^{13}$ It is thus likely that the better export performance

\footnotetext{
${ }^{13}$ Location-sector average productivity is calculated based on firm-level Total Factor Productivity (TFP), from the GMM estimation of a production function. See Section 6 for more details.
} 
in the selected locations is explained by higher productivity.

These first results then show that the public authorities selected locations which performed well in the sectors prioritized. In a given sector, firms located in the départements with a selected cluster performed on average better than did firms in the same sector located in other départements.

Three different mechanisms may explain this premium. First, a selection effect implies that only the best-performing firms survive in clusters, due to the tougher competition in these denser areas (Melitz and Ottaviano, 2008). Second, this selection effect could be reinforced by spatial sorting. In a model with heterogeneous firms, Baldwin and Okubo (2006) show that when firms relocate, the more productive ones will be the first to move from the periphery to the core. Finally, local natural advantages and agglomeration economies, which are more intense in clusters, can also explain why cluster firms have a productive advantage over non-cluster firms. Which effect dominates? Combes et al. (2008) show that spatial sorting is important for workers. However, for firms, Combes et al. (2012) find that the productivity differences between French cities cannot be explained by selection. This suggests an important role for agglomeration economies and natural advantages to explain firm productivity differences across regions. This is consistent with work showing that an important determinant of firms' location decisions is the number of firms already located in the region (Crozet et al., 2004, for France; Devereux et al., 2007, for the UK) ${ }^{14}$

We thus conclude that the ex ante productivity premium in French competitiveness clusters mainly reflects better endowments and greater agglomeration economies in the targeted areas. However, apart from this ex ante premium, the policy might also generate ex post firm relocations, with some firms moving to the targeted areas in order to benefit from the R\&D subsidies offered. Viladecans-Marsal and Arauzo-Carod (2011) find evidence of such relocations following the cluster policy implemented in Barcelona. Mayer et al. (2012) also find displacement effects in the case of a French enterprise zones policy: ${ }^{15}$ they show in particular that the impact of subsidies on firm location choice is stronger

\footnotetext{
${ }^{14}$ Note that spatial sorting of workers might affect the intensity of agglomeration economies. Saito and Gopinath (2011) use Chilean data to show that firms benefit more from spillovers when they have high skill intensity.

${ }^{15}$ The Zones Franches Urbaines policy, aiming at improving the attractiveness of French depressed urban areas.
} 
for relocations than for "pure" creations, where the former represent around one third of plant creations per annum in France. Firm location dynamics are thus an important issue for the ex post evaluation of French competitiveness clusters.

Our results so far have shown that, within a given sector, the Competitiveness cluster policy targeted the best-performing locations. However, this does not prove that these clusters ultimately grouped together the champions in the selected sectors. The firms themselves could decide whether to participate in a cluster, and the following section explores the effectiveness of this self-selection by firms.

\section{Firms in clusters have better export performance}

This section moves from average sector-location to firm-level performance. We concentrate on exporting firms (around 50\% of cluster firms are exporters) and ask whether, conditional on exporting, selected firms in the selected clusters perform on average better than do firms outside the clusters. We thus estimate the same regression as Equation 2, but now at the firm-level. The difficulty is that exports are declared by firms, not by plants. It is thus difficult to control for location-specific variables. Moreover, some firms appear in a number of different clusters. We thus include a dummy variable for multicluster firms to reflect this and control for the potentially particular premium of these firms.

The results for firm-level export values in 2004 are presented in Table 4. There are 111,960 observations. The coefficient on the cluster dummy in column 1, estimated without any other controls, suggests clear-cut conclusion: firms participating in clusters exported more than did others before entering the competitiveness clusters. From column 2 onwards we account for the endogenous selection of sectors by the competitiveness cluster policy, via sector fixed effects. The Customs database allows us to identify each firm's sector at the HS2 level ${ }^{16}$ Even after controlling for sector fixed effects, the cluster dummy continues to attract a positive significant coefficient. This indicates that, within a given sector, competitiveness cluster firms export on average $12.5[\exp (2.526)]$ times more than do other firms. In column 3, the problem of multi-cluster firms is tackled: the estimated

\footnotetext{
${ }^{16}$ This level is chosen since it decomposes trade into 98 different sectors, which is similar to the decomposition proposed by the NAF 3-digit nomenclature (87 categories).
} 
Table 4: Competitiveness clusters and export value (Customs dataset)

\begin{tabular}{||l|ccccc||}
\hline \hline \multirow{2}{*}{ Model: } & \multicolumn{4}{|c||}{ Dependent Variable: ln export value in 2004 } \\
\cline { 2 - 6 } & $(1)$ & $(2)$ & $(3)$ & $(4)$ & $(5)$ \\
\hline Competitiveness Cluster & $2.826^{a}$ & $2.526^{a}$ & $2.332^{a}$ & \\
Multi-competitiveness cluster firm & $(0.176)$ & $(0.107)$ & $(0.109)$ & \\
& & & $1.709^{a}$ & & $1.743^{a}$ \\
Best category: WCC & & & $(0.238)$ & & $(0.205)$ \\
& & & & $3.001^{a}$ & $2.494^{a}$ \\
Best category: PWCC & & & & $(0.271)$ & $(0.182)$ \\
& & & & $2.313^{a}$ & $1.926^{a}$ \\
Best category: NCC & & & & $(0.20)$ & $(0.228)$ \\
& & & & $2.477^{a}$ & $2.371^{a}$ \\
\hline Number of observations (firms) & 111960 & 111960 & 111960 & 111960 & 111960 \\
$\mathrm{R}^{2}$ & 0.023 & 0.088 & 0.089 & 0.088 & 0.089 \\
\hline \hline
\end{tabular}

Note: Sector fixed effects at the customs HS2-digit level are introduced in all columns apart from column 1. Standard errors are clustered at the HS2-digit level.

coefficient on the cluster dummy is slightly reduced, however the story remains basically unchanged. Columns 4 and 5 address the heterogeneity between the three categories of clusters. Column 4 lists the results allowing each cluster category to have different coefficients. In column 5, we further control for multi-cluster firms. Overall, the results show that, for a given sector, cluster firms export more than non-participating firms. The premium associated with clusters ranges from around $1000 \%$ for potentially worldwide clusters to $2000 \%$ for worldwide clusters, with an extra-premium for multi-clustered firms. The total value of exports is however only one basic measure of export performance. We now use the extra information available in the customs data to better characterize export performance. Four variables are considered: the unit value (a proxy for prices and quality), product diversification (the number of different products exported by a firm), market diversification (the number of destinations to which the firm ships), and the ability to export to more remote markets (the average distance from France to the destination countries).

Table (5) displays the results for the various proxies of export performance in 2004. On average, cluster firms export more, and their products have higher price-quality; they also have a larger portfolio of exported products, shipped to a wider set of markets. 
Table 5: Competitiveness clusters and export performance(Customs dataset)

\begin{tabular}{||l|cccccc||}
\hline \hline \multirow{3}{*}{ Model: } & \multicolumn{5}{|c||}{ Dependent Variable: Performance in 2004 } \\
\cline { 2 - 7 } & Exp. val. & Exp. qty & Unit val. & No. of prod. & No. of dest. & $\begin{array}{c}\text { Weighted } \\
\text { distance }\end{array}$ \\
\hline Best category: WCC & $2.494^{a}$ & $0.998^{a}$ & $1.957^{a}$ & $18.541^{a}$ & $10.463^{a}$ & $0.123^{b}$ \\
& $(0.182)$ & $(0.212)$ & $(0.142)$ & $(2.908)$ & $(1.556)$ & $(0.053)$ \\
Best category: PWCC & $1.926^{a}$ & $1.461^{a}$ & $0.839^{a}$ & $9.295^{a}$ & $8.564^{a}$ & $0.185^{a}$ \\
& $(0.228)$ & $(0.314)$ & $(0.142)$ & $(2.546)$ & $(1.429)$ & $(0.063)$ \\
Best category: NCC & $2.371^{a}$ & $2.056^{a}$ & $0.540^{a}$ & $10.216^{a}$ & $8.179^{a}$ & $-0.136^{a}$ \\
& $(0.136)$ & $(0.140)$ & $(0.105)$ & $(1.751)$ & $(0.678)$ & $(0.032)$ \\
Multi-competitiveness & $1.743^{a}$ & $1.771^{a}$ & $0.296^{b}$ & $32.446^{a}$ & $14.887^{a}$ & 0.110 \\
cluster firm & $(0.205)$ & $(0.281)$ & $(0.130)$ & $(7.115)$ & $(1.634)$ & $(0.069)$ \\
\hline Number of obs. (firms) & 111960 & 111552 & 111552 & 111960 & 111960 & 111960 \\
$\mathrm{R}^{2}$ & 0.089 & 0.251 & 0.46 & 0.033 & 0.067 & 0.093 \\
\hline \hline
\end{tabular}

Note: Performance indicators are in Ln except for the number of products and the number of destinations. Fixed effects at the HS2-digit level are introduced in all columns. Standard errors are clustered at the HS2-digit level.

These general results are however fairly heterogeneous across the different cluster types. In "National" clusters, firms export more, but the quality premium is lower compared to "Worldwide" clusters. On the other hand, firms in "Worldwide" clusters export many more products to many more destinations than do firms in the other cluster types. There is moreover a premium for multi-cluster firms in each of these dimensions. Last, the premium of firms in "National" clusters is negative in terms of exporting to remote markets: firms in this group do not appear to be "global players".

To summarize, these results show that subsidized firms in the French competitiveness clusters policy had better export performance than other firms before the implementation of the policy: the French authorities subsidized firms that had an ex ante export premium, which is a proxy for efficiency. The French authorities thus seem to have managed, through the two-stage selection process (sector-location pairs and then firms), to extract information on winners. The next section explores whether this information on the export premium goes beyond firm observable characteristics (such as productivity and size), i.e. whether the geographical clustering of firms as such already adds ex ante to the firmspecific premium. 


\section{Controlling for individual characteristics eliminates the competitiveness premium}

The previous section demonstrated that firms participating in competitiveness clusters perform overall better than do other firms. The recent theoretical literature on firm heterogeneity stresses that firms with greater efficiency also have better export performance. The export premium observed for firms in clusters thus might simply reflect selection bias: firms in clusters are just the most productive ones. We would thus like to check whether we still observe an export premium for firms in clusters once their individual characteristics have been controlled for. To answer this question, we use the manufacturing ABS dataset and introduce controls for the individual firm characteristics. Our sample is reduced to 13,857 exporting firms, of which 1,010 belong to a competitiveness cluster. To calculate firm-level total factor productivity, we estimate a Cobb-Douglas production function. We then require information on firm value-added, number of employees and capital; we consequently limit our exercise to the 13,510 exporting firms present in the ABS, which may or may not be cluster members for which the relevant data is available. The estimation of production functions is subject to a number of drawbacks that we address via GMM estimation, following Griliches and Mairesse (1996) and Bond (2002) (see the Appendix).

Table $\mathrm{A}-2$ in the Appendix replicates the results of Table (5) using this restricted sample. The estimates confirm that the firms subsidized in the French competitiveness clusters had better export performance, such as greater export value and unit value, more exported products and more numerous and more remote export destinations, than did the other exporters present in the ABS.

For the sake of clarity we first focus on the export value. We regress the log value of firm exports in the ABS, and we then compare our previous results to those obtained with this new sample comprising 13,510 observations. Column 1 of Table (6) controls for firm size and productivity. Fixed effects at the 3-digit level are included in columns 2 to 5. Fixed effects at the département/2-digit sector and at the département/3-digit sector are respectively introduced in columns 6 and 7. Standard errors are clustered at the 3-digit level in columns 1 to 5 , at the département/2-digit level in column 6 , and at the département/3-digit level in column 7. 
Table 6: Competitiveness clusters and export value (Customs + ABS dataset)

\begin{tabular}{||l|cccccccc||}
\hline \hline \multirow{3}{*}{ Model: } & \multicolumn{7}{|c||}{ Dependent Variable: ln export value in 2004 } \\
\cline { 2 - 9 } & $(1)$ & $(2)$ & $(3)$ & $(4)$ & $(5)$ & $(6)$ & $(7)$ \\
\hline Competitiveness Cluster & $0.509^{a}$ & $0.337^{a}$ & $0.312^{a}$ & & & & \\
& $(0.116)$ & $(0.098)$ & $(0.104)$ & & & & \\
& ln Number of employees & $1.320^{a}$ & $1.269^{a}$ & $1.266^{a}$ & $1.271^{a}$ & $1.268^{a}$ & $1.274^{a}$ & $1.233^{a}$ \\
ln IV total factor & $(0.048)$ & $(0.038)$ & $(0.039)$ & $(0.039)$ & $(0.039)$ & $(0.031)$ & $(0.031)$ \\
productivity & $0.771^{a}$ & $0.772^{a}$ & $0.771^{a}$ & $0.773^{a}$ & $0.771^{a}$ & $0.738^{a}$ & $0.746^{a}$ \\
Multi-competitiveness & $(0.117)$ & $(0.058)$ & $(0.058)$ & $(0.059)$ & $(0.059)$ & $(0.057)$ & $(0.058)$ \\
cluster firm & & & 0.204 & & $0.290^{c}$ & $0.360^{b}$ & $0.441^{b}$ \\
Best category is WCC & & & $(0.168)$ & & $(0.167)$ & $(0.163)$ & $(0.180)$ \\
& & & & 0.152 & 0.077 & 0.050 & 0.052 \\
Best category is PWCC & & & & $(0.226)$ & $(0.228)$ & $(0.201)$ & $(0.232)$ \\
& & & & 0.124 & 0.059 & -0.013 & 0.042 \\
Best category is NCC & & & & $0.175)$ & $(0.178)$ & $(0.198)$ & $(0.222)$ \\
& & & & $0.404^{a}$ & $0.382^{a}$ & $0.289^{a}$ & $0.229^{b}$ \\
Number of obs. (firms) & 13510 & 13510 & 13510 & 13510 & $(0.140)$ & $(0.086)$ & $(0.097)$ \\
$\mathrm{R}^{2}$ & 0.328 & 0.425 & 0.426 & 0.426 & 0.426 & 13510 & 13510 \\
\hline \hline
\end{tabular}

Note: Fixed effects at the 3-digit level are introduced in columns 2 to 5 . Fixed effects at the département/NAF2 digit and at the département/3-digit industry are respectively introduced in columns 6 and 7. Standard errors are clustered at the 3-digit level from column 1 to 5 , at the département/NAF2-digit level in column 6 and at the département/3-digit level in column 7 . 
The results in the previous section continue to hold in column 1, but the size of the "competitiveness cluster" premium is considerably reduced (now 66\% as opposed to $1700 \%)$. This comes as no surprise since the restriction of the analysis to ABS firms means that we consider larger firms, for which the dispersion of export performance may be more limited. Moreover, we now control for firm size and productivity: the lower export premium shows that larger and more productive firms self-selected into competitiveness clusters. Even so, after controlling for size and productivity, we still observe an export-value premium for competitiveness cluster firms. When the firm's sector is controlled for in column 2, this premium shrinks to $40 \%$, and is further reduced in column 3 after controlling for multi-cluster firms. More interestingly, columns 4 to 7 reveal that the general premium measured for competitiveness cluster firms is due to a composition effect. We decompose the dummy "competitiveness cluster" into three different dummies depending on cluster type: only "National" clusters contribute positively and significantly to the export premium of competitiveness cluster firms.

We thus conclude that competitiveness clusters simply group together the most efficient firms in the selected sector. After controlling for size and productivity, nothing is left in terms of a competitive premium, with the noticeable exception of "National" clusters.17 In this latter cluster type, firms do exhibit an export premium beyond their individual characteristics. Table $\mathrm{A}-3$ in the Appendix shows that the message remains unchanged when considering the growth rate of exports before the implementation of the policy (between 2001 and 2004).

Regarding the other dimensions of firm-level performance, Table 7 shows that firms in "National" clusters also exhibit a productivity premium compared to firms in the same sector-department that are not cluster members. All three categories have a premium in terms of unit-value, which is particularly large for "Worldwide" competitiveness clusters. This shows that firms in competitiveness clusters produce and export higher-quality goods than do non-cluster firms in the same sector-département. No significant premium is found

\footnotetext{
${ }^{17}$ Results available upon request show that this finding is robust to the exclusion of multi-plant firms from the sample. To uncover the determinants of this self selection process, we also used logit estimation to explain whether a firm participates in a "National" cluster based on its individual characteristics. The results show that self-selected firms are larger, probably due to the sunk costs associated with the application process, or due to better access to information and networking. These firms are also more productive and more export-oriented. Being a member of a domestic group increases the probability of entering into a cluster.
} 
Table 7: Competitiveness clusters and export performance - Firm controls (Customs + ABS)

\begin{tabular}{||l|ccccccc||}
\hline \hline \multirow{3}{*}{ Model: } & \multicolumn{7}{|c||}{ Dependent Variable: Performance in 2004 } \\
\cline { 2 - 8 } & $\begin{array}{c}\text { Export } \\
\text { value }\end{array}$ & $\begin{array}{c}\text { Export } \\
\text { quantity }\end{array}$ & $\begin{array}{c}\text { Unit. } \\
\text { value. }\end{array}$ & $\begin{array}{c}\text { Number. } \\
\text { of products }\end{array}$ & $\begin{array}{c}\text { Number of. } \\
\text { destinations }\end{array}$ & $\begin{array}{c}\text { Weighted } \\
\text { distance }\end{array}$ & TFP \\
\hline Best category is WCC & 0.052 & $-1.025^{a}$ & $1.377^{a}$ & 7.042 & 3.410 & 0.091 & 0.025 \\
& $(0.232)$ & $(0.326)$ & $(0.205)$ & $(5.746)$ & $(2.998)$ & $(0.086)$ & $(0.059)$ \\
Best category is PWCC & 0.042 & -0.210 & $0.359^{c}$ & 9.917 & 2.336 & $0.184^{c}$ & 0.078 \\
& $(0.222)$ & $(0.296)$ & $(0.187)$ & $(7.530)$ & $(2.756)$ & $(0.102)$ & $(0.054)$ \\
Best category is NCC & $0.229^{b}$ & -0.037 & $0.309^{a}$ & 1.322 & 0.618 & -0.006 & $0.052^{b}$ \\
& $(0.097)$ & $(0.112)$ & $(0.079)$ & $(1.815)$ & $(0.833)$ & $(0.040)$ & $(0.022)$ \\
Multi-competitiveness & $0.441^{b}$ & 0.256 & $0.367^{b}$ & $25.479^{a}$ & $10.143^{a}$ & -0.002 & $0.119^{b}$ \\
cluster firm & $(0.180)$ & $(0.212)$ & $(0.171)$ & $(7.938)$ & $(3.177)$ & $(0.080)$ & $(0.047)$ \\
ln Number of employees & $1.233^{a}$ & $1.351^{a}$ & -0.007 & $10.977^{a}$ & $7.255^{a}$ & $0.063^{a}$ & $0.049^{a}$ \\
& $(0.031)$ & $(0.039)$ & $(0.021)$ & $(0.843)$ & $(0.239)$ & $(0.009)$ & $(0.006)$ \\
ln IV total factor & $0.746^{a}$ & $0.617^{a}$ & $0.154^{a}$ & $6.052^{a}$ & $3.717^{a}$ & $0.071^{a}$ & \\
productivity & $(0.058)$ & $(0.064)$ & $(0.038)$ & $(0.694)$ & $(0.430)$ & $(0.021)$ & \\
\hline Number of observations & 13510 & 13500 & 13500 & 13510 & 13510 & 13510 & 13510 \\
$\mathrm{R}^{2}$ & 0.298 & 0.242 & 0.015 & 0.217 & 0.261 & 0.008 & 0.014 \\
\hline
\end{tabular}

Note: Fixed effects at the département/Naf 3-digit level are introduced in all columns. Performance indicators are in Ln except the number of products and the number of destinations. Standard errors are clustered at the département/Naf 3-digit level.

for the other dimensions of export performance once firm size, productivity and presence in more than one cluster is taken into account.

It should be noted that firms are not necessarily financially independent ${ }^{18}$ They often belong to a group where decisions made at the headquarters level affect the individual export performance of affiliates. The nationality of the group is also likely to affect firm performance. Last, firms can be single- or multi-plant. If these variables are correlated with competitiveness cluster membership, then they could be behind the observed premium for "National" clusters. We try to control for the different types of selection by merging our data with information on the (domestic and international) financial linkages between firms. These come from the LIFI database, constructed by the French National Institute for Statistics. We check in Table $(\mathrm{A}-4)$ in the Appendix whether we continue to see an export performance premium for "National" clusters only after controlling for these dimensions. ${ }^{19}$ The results, in column 5 onwards of this table, also appear to be robust to

\footnotetext{
${ }^{18}$ French Customs record exports at the company level.

${ }^{19}$ The scope of the firm, as proxied by the number of plants, has no statistically significant effect. On the contrary, belonging to a group increases export performance, and this effect is larger when the group is foreign-owned. Depending on the structure of the group, however, this impact can be magnified or reduced. Finally, groups focused on the French market (with a large number of domestic affiliates) are
} 
the inclusion of firm-level wages. We also obtain analogous results from the same strategy applied to the performance growth rate between 2001 and 2004 (see Tables $(\mathrm{A}-5)$ and $\mathrm{A}-$ 6).

\section{Conclusion}

The results in this paper have shown that despite the considerable number of clusters subsidized by the French competitiveness cluster policy, the process was actually rather selective: only $2 \%$ of manufacturing exporters are members of a competitiveness cluster. This final tally results from the selection of clusters (sector-location couples) by the national authorities, and then the self-selection of individual firms as cluster members in order to apply for the subsidies available to the selected clusters.

The empirical outcome of this two-stage process is clear. The first stage yields clusters of firms that perform on average better within their sector at the national level. The second stage induced firms which performed better than others in the same sector-location pair to self-select as cluster members. This is true for all three cluster types. However, with the exception of "National" clusters, the export premia are fully explained by individual firm characteristics: the geographical clustering of firms as such does not add anything to the ex ante premium for the other cluster categories. In the first two cluster categories, national champions were then (self)-selected according to their size and productivity. They however had no ex ante export premium beyond these individual characteristics (except for quality, proxied by export unit value). For "National" clusters, which were the most heterogeneous, things are rather different. Firms in these clusters export more than do others, even after controlling for size and productivity. This could mean that firms in "National" clusters benefit from export spillovers or have a specific ability, beyond individual productivity or size, that makes them future potential champions.

We believe that this paper provides an interesting methodology that could be replicated to evaluate cluster policies and more generally, industrial policies with geographical scope based on calls for tender. It also opens up avenues for future research. In particular, whether the subsidy type ( $R \& D$ versus employment incentives, big versus small moneless export-oriented, while the effect for groups focused on international markets is the opposite. 
tary subsidies etc.) plays a role in the self-selection of firms remains an open question. Comparative work may well help in this respect. 


\section{References}

ARTus, P. And Fontagné, L., 2006, "Evolution récente du commerce extérieur français", public report from the Conseil d'Analyse Economique, No. 64.

Aw B., M. J. Roberts And D.Y. Xu, 2011, "R\&D Investment, Exporting, and Productivity Dynamics," American Economic Review, 101(4): 1312-44.

Baldwin R. And T. Okubo, 2006, "Heterogeneous Firms, Agglomeration and Economic Geography", Journal of Economic Geography, 6, 323-346.

Baldwin R. And T. Okubo, 2009, "Tax Reform, Delocation, and Heterogeneous Firms,", Scandinavian Journal of Economics, 111(4), 741-764.

BAldwin R. And F. Robert-Nicoud, 2007, "Entry and Asymmetric Lobbying: Why Governments Pick Losers", Journal of the European Economic Association, 5(5), 1064-1093.

Barca F., P. MCCAnn And A. Rodriguez-Pose , 2012, "The case for regional development intervention: Place-based vs place-neutral approaches", Journal of Regional Science, 52(1), 134-152.

Beason R. And D.E. Weinstein, 1996, "Growth, Economies of Scale and Targeting in Japan (1955-1990)", The Review of Economics and Statistics, 78(2), 286-295.

Bombardini, M., 2008, "Firm Heterogeneity and Lobby Participation", Journal of International Economics, 75(2), 329-348.

Bond S, 2002, "Dynamic panel data models: a guide to micro data methods and practice", CEMMAP Working paper, CWP09/02.

Cassiman, B. And E. Golovko, 2011, "Innovation and Internationalization through Exports', Journal of International Business Studies, 42(1), 56-75.

Combes, P-P, G. Duranton And L. Gobillon, 2008, "Spatial wage disparities: Sorting matters!", Journal of Urban Economics, 63(2), 723-742.

Combes, P-P, G. Duranton, L. Gobillon, D. Puga And S. Roux, 2012, "The productivity advantages of large cities: Distinguishing agglomeration from firm selection", Econometrica, forthcoming.

Corden M., 1974, Trade Policy and Economic Welfare, Oxford University Press, Oxford.

Crisculol, C., R. Martin, H. Overman, And J. Van Reenen, 2012, "The causal effect of an industrial policy", CEPR Discussion Paper, DP8818

Crozet, M. And T. Mayer And J-L Mucchielli, 2004, "How do firms Agglomerate? A Study of FDI in France", Regional Science and Urban Economics, 34(1), 27-54. 
Devereux, M., R. Griffith and H. Simpson, 2007, "Firm location decisions, regional grants and agglomeration externalities", Journal of Public Economics, 91(34), 413-435.

Duranton, G.,, 2011, "California dreamin': The feeble case for cluster policies", Review of Economic Analysis, 3(1), 3-45.

Duranton, G., P. Martin, T. Mayer And F. Mayneris, 2011, The Economics of Clusters, Oxford University Press.

Engel, D., T. Mitze, R. Patuelli And J. Reinkowski, 2011, "Does the support of innovative clusters sustainably foster R\&D activity? Evidence from the German BioRegio and BioProfile contests", Rimini Centre for Economic Analysis Working Paper, WP 11-15.

Falck, O., S. Kipar et S. HeBlich, 2010, "Industrial innovation: Direct evidence from a cluster-oriented policy", Regional Science and Urban Economics, 40(6), 574582.

Griliches Z. AND Mairesse, J., 1995, "Production functions: the search for identification", NBER Working paper No. 5067.

Iacovone, L. And B. Smarzynska-Javorcik, 2012, "Getting Ready: Preparation for Exporting", mimeo.

Jaffe A.B., M. Trajtenberg And R. Henderson, 1993, "Geographic Localization of knowledge spillovers as evidenced by patent citations", Quarterly Journal of Economics, 108, 577-598.

Koenig, P., F. Mayneris And S. Poncet, 2010, "Local export spillovers in France", European Economic Review, 54, 622-641.

Koenig, P., F. Mayneris And S. Poncet, 2011, "Economies d'agglomération à l'exportation et difficultés d'accès aux marchés", Economie et Statistique, 435-436, pp. $85-103$.

KRUEGER A., 1990, "Asymmetries in policy between exportable and import competing goods", in The Political Economy of International Trade, ed. by R. Jones and A. Krueger, Basil Blackwell.

Martin P., T. Mayer And F. Mayneris, 2011a, "Spatial concentration and plantlevel productivity in France", Journal of Urban Economics, 69(2), 182-195.

Martin P., T. Mayer And F. MAYneris, 2011b, "Public support to clusters: a firm level study of French 'Local productive systems"', Regional Science and Urban Economics, 41(2), 108-123.

Martin R. And P. Sunley, 2003, "Deconstructing clusters: chaotic concept or policy panacea?", Journal of Economic Geography, 3(1), 5-35. 
Mayer T., F. MAYNeris AND L. Py, 2012, "The impact of urban enterprise zones on plants' location decisions - Evidence from French ZFUs", mimeo.

MeLitz M., 2003, "The Impact of Trade on Intra-Industry Reallocations and Aggregate Industry Productivity", Econometrica, 71(6), 1695-1725.

MAYER T. And G. OtTAviano, 2007, "The happy few: new facts on the internationalisation of European firms", Bruegel-CEPR EFIM2007 Report, Bruegel Blueprint Series.

Melitz M. And G.I.P. Ottaviano, 2008, "Market size, Trade and Productivity", The Review of Economic Studies, 75(1), 295-316.

Nishimura. J. AND H. OkAmuro, 2011, "R\&D productivity and the organization of cluster policy: An empirical evaluation of the Industrial Cluster Project in Japan", The Journal of Technology Transfer, 36(2), 117-144.

OkuBO, T. , 2012, "Antiagglomeration subsidies with heterogeneous firms', Journal of Regional Science, 52(2), 285-299.

PorTer M., 1998, "Clusters and the new economics of competition", Harvard Business Review, 76 (6), 77-91.

PorTer M., 2000, "Location, competition and economic development: local clusters in a global economy", Economic Development Quarterly, 14 (1), 15-34.

Rosenthal, J.S. And W. Strange, 2004, "Evidence on the nature and sources of agglomeration economies" in Handbook of Regional and Urban Economics,, ed. by J. V. Henderson, and J. F. Thisse, Vol. 4 of Handbook of Regional and Urban Economics, Chap.49, pp. 2119-2171. Elsevier.

SAito H. AND M. Gopinath, 2011, "Knowledge spillovers, absorptive capacity and skill intensity of Chilean manufacturing firms", Journal of Regional Science, 51(1), 83-101.

Solvell, O., G. Lindqvist And C. Ketels, 2003, "The Cluster Initiative Greenbook", Stockholm: Ivory Tower.

Van Beveren I. And H. Vandenbussche, 2010, "Product and process innovation and firms' decision to export", Journal of Economic Policy Reform, 13(1), 3-24.

Viladecans-Marsal E. AND J-M, Arauzo-Carod, 2011, "Can a knowledge-based cluster be created? The case of the Barcelona 22@ district", Papers in Regional Science, 91(2), 377-400. 


\section{A-1 Appendix: The estimation of production functions}

Two main issues arise when estimating production functions:

- Unobserved heterogeneity: Some characteristics, unobserved by the econometrician, may be related to both firm value added and input levels chosen by the firm. Consequently, the OLS estimation of input elasticities are potentially biased, as the endogenous variables will partly capture the effect of unobserved characteristics. For example, less risk-averse firms may distort their labor-capital mix in a particular way, have different innovation strategies and also seek more risky (and potentially more profitable) markets. Not taking firm fixed characteristics into account potentially biases the estimation of returns to capital and labour.

- Simultaneity: At the beginning of the year, the firm may anticipate a positive (or negative) economic shock and consequently decide on the amount of capital and labor to use. From an econometric point of view, there is possible reverse causality: the amount of capital and labour are determined by firm decisions regarding the level of output, rather than the opposite.

To solve both of these issues, we use an instrumental variables approach. The method follows Bond (2002) and Griliches and Mairesse (1995): we start by taking first-differences of each variable, to address unobserved heterogeneity. We then instrument the firstdifferenced independent variables by their level at time $t-2$. The underlying econometric assumption is that the idiosyncratic shock at time $t-2$ is orthogonal to the difference in the shocks in $t$ and $t-1$. Under this assumption, the instruments are exogenous. We find elasticities of 0.75 for labour and 0.17 for capital, which are in line with the literature.20

\footnotetext{
${ }^{20}$ Due to an insufficient number of observations for some industries, we estimate a single production function for all manufacturing industries. However, Martin et al. (2011a and b) find, using the same French data as here, that the choice of the estimation procedure for production function does not affect their results.
} 
Table A-1: Descriptive statistics regarding competitiveness clusters

\begin{tabular}{|c|c|c|c|c|c|c|c|c|}
\hline \multirow[t]{2}{*}{ Name } & \multirow[t]{2}{*}{ Category } & \multirow{2}{*}{$\begin{array}{l}\text { No. } \\
\text { firms }\end{array}$} & \multirow{2}{*}{$\begin{array}{l}\text { No. export- } \\
\text { ing } \\
\text { firms }\end{array}$} & \multirow{2}{*}{$\begin{array}{l}\text { Share of } \\
\text { exporting } \\
\text { firms }\end{array}$} & \multicolumn{2}{|c|}{ Size of firms } & \multicolumn{2}{|c|}{ Size of exporting firms } \\
\hline & & & & & Mean & Median & Mean & Median \\
\hline A.E.S.E. & 1 & 365 & 160 & 0.44 & 1035 & 43 & 2080 & 143 \\
\hline Lyon Biopole & 1 & 28 & 14 & 0.50 & 916 & 46 & 1624 & 316 \\
\hline Minalogic & 1 & 47 & 34 & 0.72 & 3623 & 143 & 4523 & 148 \\
\hline MédiTech Santé & 1 & 53 & 17 & 0.32 & 265 & 12 & 757 & 143 \\
\hline SYSTEM@TIC Paris-région & 1 & 133 & 65 & 0.49 & 5310 & 43 & 10660 & 696 \\
\hline $\begin{array}{l}\text { Solutions } \\
\text { Sécurisées }\end{array}$ & 1 & 59 & 33 & 0.56 & 3620 & 57 & 5390 & 73 \\
\hline Mean & 1 & 114 & 54 & 0.47 & 2462 & 57 & 4172 & 253 \\
\hline $\begin{array}{l}\text { AXELERA Chimie-environnement } \\
\text { Lyon }\end{array}$ & 2 & 63 & 36 & 0.57 & 1232 & 99 & 1885 & 239 \\
\hline $\begin{array}{llr}\text { Image, } & \text { Multimédia et } & \text { Vie } \\
\text { Numérique - CAP DIGITAL } & \end{array}$ & 2 & 228 & 47 & 0.21 & 864 & 15 & 3433 & 49 \\
\hline Images \& Réseaux & 2 & 108 & 36 & 0.33 & 1664 & 23 & 4545 & 78 \\
\hline Industries et Agroressources & 2 & 50 & 34 & 0.68 & 7500 & 150 & 10221 & 174 \\
\hline Innovations thérapeutiques & 2 & 29 & 15 & 0.52 & 208 & 12 & 397 & 182 \\
\hline Mer Bretagne & 2 & 135 & 59 & 0.44 & 1356 & 18 & 2727 & 35 \\
\hline Mer, sécurité et sûreté & 2 & 141 & 47 & 0.33 & 518 & 23 & 1053 & 115 \\
\hline Moveo & 2 & 43 & 27 & 0.63 & 3779 & 329 & 5500 & 994 \\
\hline Pôle i-Trans & 2 & 46 & 29 & 0.63 & 6463 & 219 & 9625 & 340 \\
\hline Végétal spécialisé & 2 & 53 & 30 & 0.57 & 164 & 16 & 200 & 77 \\
\hline Mean & 2 & 90 & 36 & 0.40 & 2375 & 90 & 3959 & 228 \\
\hline ARVE industrie & 3 & 137 & 94 & 0.69 & 118 & 25 & 156 & 39 \\
\hline Auto haut de gamme & 3 & 45 & 28 & 0.62 & 2302 & 55 & 596 & 285 \\
\hline Biothérapies & 3 & 39 & 11 & 0.28 & 180 & 10 & 370 & 35 \\
\hline Capenergies & 3 & 97 & 31 & 0.32 & 1965 & 13 & 5227 & 164 \\
\hline Cosmetic valley & 3 & 103 & 51 & 0.50 & 142 & 24 & 215 & 43 \\
\hline $\begin{array}{l}\text { DERBI Energie renouvelable bâti- } \\
\text { ment industrie }\end{array}$ & 3 & 57 & 21 & 0.37 & 587 & 20 & 1283 & 63 \\
\hline ELOPSYS & 3 & 20 & 6 & 0.30 & 819 & 20 & 1902 & 765 \\
\hline $\mathrm{EMC} 2$ & 3 & 57 & 34 & 0.60 & 777 & 69 & 1192 & 99 \\
\hline EnRRDIS & 3 & 17 & 9 & 0.53 & 8979 & 444 & 15843 & 1232 \\
\hline Fibres naturelles Grand Est & 3 & 24 & 15 & 0.63 & 269 & 106 & 339 & 147 \\
\hline Filière produits aquatiques & 3 & 7 & 7 & 1.00 & 238 & 117 & 238 & 117 \\
\hline Filière équine & 3 & 48 & 13 & 0.27 & 40 & 4 & 110 & 20 \\
\hline $\begin{array}{l}\text { Gestion des risques et vulnérabilités } \\
\text { des territoir }\end{array}$ & 3 & 81 & 27 & 0.33 & 3429 & 37 & 8065 & 942 \\
\hline Imaginov & 3 & 121 & 11 & 0.09 & 92 & 4 & 50 & 23 \\
\hline Industries du commerce & 3 & 38 & 19 & 0.50 & 3359 & 64 & 6575 & 2142 \\
\hline Innovation dans les céréales & 3 & 21 & 11 & 0.52 & 262 & 111 & 164 & 117 \\
\hline L'aliment de demain & 3 & 116 & 76 & 0.66 & 274 & 54 & 362 & 91 \\
\hline Logistique Seine-Normandie & 3 & 58 & 30 & 0.52 & 9759 & 222 & 18568 & 368 \\
\hline Lyon Urban Truck \& Bus 2015 & 3 & 33 & 19 & 0.58 & 987 & 77 & 1637 & 349 \\
\hline $\begin{array}{l}\text { MAUD Matériaux à usage domes- } \\
\text { tique }\end{array}$ & 3 & 15 & 13 & 0.87 & 1286 & 188 & 1477 & 357 \\
\hline $\begin{array}{l}\text { Matériaux Innovants, Produits In- } \\
\text { telligents (MIPI) }\end{array}$ & 3 & 18 & 16 & 0.89 & 1118 & 192 & 650 & 192 \\
\hline Mobilité et transports avancés & 3 & 34 & 24 & 0.71 & 11233 & 1468 & 15397 & 1873 \\
\hline Nutrition santé longévité & 3 & 29 & 18 & 0.62 & 253 & 26 & 397 & 99 \\
\hline Orpheme & 3 & 111 & 53 & 0.48 & 54 & 14 & 89 & 38 \\
\hline Parfums, arômes, senteurs, saveurs & 3 & 46 & 32 & 0.70 & 384 & 31 & 521 & 47 \\
\hline Photonique & 3 & 58 & 37 & 0.64 & 495 & 14 & 725 & 32 \\
\hline Pin maritime du futur & 3 & 56 & 37 & 0.66 & 110 & 27 & 144 & 47 \\
\hline Prod'Innov & 3 & 60 & 42 & 0.70 & 397 & 55 & 552 & 183 \\
\hline $\begin{array}{l}\text { Pôle agronutrition en milieu tropi- } \\
\text { cal }\end{array}$ & 3 & 13 & 3 & 0.23 & 78 & 60 & 93 & 125 \\
\hline Pôle cancer-bio-santé & 3 & 47 & 18 & 0.38 & 707 & 28 & 1215 & 40 \\
\hline Pôle céramique & 3 & 50 & 37 & 0.74 & 144 & 45 & 184 & 72 \\
\hline Pôle des microtechniques & 3 & 390 & 253 & 0.65 & 69 & 14 & 99 & 21 \\
\hline Pôle enfant & 3 & 38 & 27 & 0.71 & 186 & 102 & 230 & 150 \\
\hline $\begin{array}{l}\text { Pôle européen d'innovation Fruits } \\
\text { et Légumes }\end{array}$ & 3 & 68 & 35 & 0.51 & 225 & 26 & 287 & 49 \\
\hline Pôle génie civil Ouest & 3 & 35 & 12 & 0.34 & 669 & 292 & 1047 & 656 \\
\hline Pôle nucléaire Bourgogne & 3 & 55 & 33 & 0.60 & 4188 & 70 & 6441 & 96 \\
\hline Pôle plasturgie & 3 & 101 & 66 & 0.65 & 167 & 43 & 237 & 83 \\
\hline Q@LIMED Agropolis & 3 & 20 & 12 & 0.60 & 1226 & 31 & 2002 & 98 \\
\hline Route des lasers & 3 & 47 & 24 & 0.51 & 3354 & 42 & 5859 & 171 \\
\hline SPORALTEC & 3 & 18 & 14 & 0.78 & 1207 & 134 & 1475 & 185 \\
\hline $\begin{array}{l}\text { Sciences et Systèmes de l'Energie } \\
\text { Electrique }\end{array}$ & 3 & 44 & 29 & 0.66 & 3767 & 57 & 5316 & 76 \\
\hline Techtera & 3 & 39 & 32 & 0.82 & 124 & 48 & 138 & 50 \\
\hline $\begin{array}{l}\text { Transactions } \\
\text { sécurisées }\end{array}$ & 3 & 58 & 22 & 0.38 & 3851 & 27 & 9196 & 204 \\
\hline Trimatec & 3 & 42 & 24 & 0.57 & 3322 & 76 & 5716 & 421 \\
\hline UP-TEX & 3 & 51 & 39 & 0.76 & 1180 & 70 & 1483 & 99 \\
\hline VIAMECA & 3 & 40 & 26 & 0.65 & 3854 & 71 & 5482 & 118 \\
\hline Viandes et produits carnés & 3 & 427 & 186 & 0.44 & 164 & 36 & 318 & 91 \\
\hline Ville et mobilité durables & 3 & 33 & 12 & 0.36 & 11141 & 82 & 33226 & 262 \\
\hline Vitagora & 3 & 83 & 53 & 0.64 & 509 & 71 & 343 & 81 \\
\hline Véhicule du futur & 3 & 228 & 180 & 0.79 & 1044 & 143 & 1275 & 182 \\
\hline Mean & 3 & 69 & 38 & 0.55 & 1822 & 101 & 3290 & 265 \\
\hline
\end{tabular}

Note: Categories 1, 2 and 3 are "worldwide competitiveness clusters", "potentially worldwide competitiveness clusters" and "national competitiveness clusters" respectively. The statistics for the share of exporters are calculated using both the customs dataset and the competitiveness cluster data from the French Ministry of Finance. 
Table A-2: Competitiveness clusters and export performance (Customs + ABS dataset)

\begin{tabular}{||l|cccccc||}
\hline \hline \multirow{3}{*}{ Model: } & \multicolumn{5}{|c||}{ Dependent Variable: Performance in 2004 } \\
\cline { 2 - 7 } & Exp. val. & Exp. qty & Unit val. No. of prod. & No. of dest. & $\begin{array}{c}\text { Weighted } \\
\text { distance }\end{array}$ \\
\hline Best category is WCC & $1.490^{a}$ & -0.157 & $2.145^{a}$ & $21.631^{a}$ & $8.864^{a}$ & $0.214^{a}$ \\
& $(0.317)$ & $(0.226)$ & $(0.252)$ & $(5.611)$ & $(2.795)$ & $(0.059)$ \\
Best category is PWCC & $1.554^{a}$ & $1.370^{a}$ & 0.375 & $20.227^{a}$ & $11.011^{a}$ & $0.249^{a}$ \\
& $(0.285)$ & $(0.437)$ & $(0.238)$ & $(6.394)$ & $(2.738)$ & $(0.085)$ \\
Best category is NCC & $1.312^{a}$ & $0.947^{a}$ & $0.517^{a}$ & $8.677^{a}$ & $5.832^{a}$ & 0.022 \\
& $(0.176)$ & $(0.234)$ & $(0.088)$ & $(2.321)$ & $(0.828)$ & $(0.026)$ \\
Multi-competitiveness & $1.994^{a}$ & $2.163^{a}$ & 0.106 & $41.684^{a}$ & $19.325^{a}$ & $0.208^{a}$ \\
cluster firm & $(0.276)$ & $(0.319)$ & $(0.133)$ & $(7.848)$ & $(3.019)$ & $(0.056)$ \\
\hline Number of observations & 13510 & 13500 & 13500 & 13510 & 13510 & 13510 \\
$\mathrm{R}^{2}$ & 0.105 & 0.168 & 0.443 & 0.174 & 0.122 & 0.089 \\
\hline \hline
\end{tabular}

Note: Performance indicators are in Ln except for the number of products and the number of destinations. Fixed effects at the HS2-digit level are introduced in all columns. Standard errors are clustered at the HS2-digit level.

Table A-3: Competitiveness clusters and export value growth (Customs + ABS)

\begin{tabular}{||l|ccccccc||}
\hline \hline \multirow{3}{*}{ Model: } & \multicolumn{7}{|c||}{ Dependent Variable: $\Delta$ ln export in 2004 } \\
\cline { 2 - 8 } & $(1)$ & $(2)$ & $(3)$ & $(4)$ & $(5)$ & $(6)$ & $(7)$ \\
Number of employees in 2001 & $0.246^{a}$ & $0.261^{a}$ & $0.261^{a}$ & $0.262^{a}$ & $0.261^{a}$ & $0.266^{a}$ & $0.268^{a}$ \\
& $(0.020)$ & $(0.019)$ & $(0.020)$ & $(0.020)$ & $(0.020)$ & $(0.019)$ & $(0.022)$ \\
Ln export value in 2001 & $0.199^{a}$ & $0.223^{a}$ & $0.223^{a}$ & $0.223^{a}$ & $0.223^{a}$ & $0.223^{a}$ & $0.267^{a}$ \\
& $(0.060)$ & $(0.045)$ & $(0.045)$ & $(0.045)$ & $(0.045)$ & $(0.036)$ & $(0.043)$ \\
Competitiveness cluster (CC) & $-0.192^{a}$ & $-0.220^{a}$ & $-0.220^{a}$ & $-0.220^{a}$ & $-0.220^{a}$ & $-0.217^{a}$ & $-0.234^{a}$ \\
& $(0.012)$ & $(0.012)$ & $(0.012)$ & $(0.012)$ & $(0.012)$ & $(0.010)$ & $(0.012)$ \\
Multi-competitiveness cluster firm & $0.178^{a}$ & $0.145^{a}$ & $0.139^{a}$ & & & & \\
& $(0.043)$ & $(0.043)$ & $(0.047)$ & & & & \\
Best category is WCC & & & 0.051 & & 0.075 & 0.151 & $0.182^{c}$ \\
& & & $(0.081)$ & & $(0.092)$ & $(0.095)$ & $(0.111)$ \\
Best category is PWCC & & & & 0.088 & 0.068 & -0.026 & 0.071 \\
& & & & $(0.146)$ & $(0.160)$ & $(0.146)$ & $(0.176)$ \\
Best category is NCC & & & & 0.095 & 0.079 & 0.011 & 0.044 \\
& & & & $0.096)$ & $(0.099)$ & $(0.136)$ & $(0.156)$ \\
Number of observations & & & & $0.163^{a}$ & $0.157^{a}$ & $0.159^{a}$ & $0.195^{a}$ \\
$\mathrm{R}^{2}$ & 10812 & 10812 & 10812 & 10812 & $(0.057)$ & $(0.052)$ & $(0.056)$ \\
\hline \hline
\end{tabular}

Note: Fixed effects at the 3-digit level are introduced in columns 2 to 5. Fixed effects at the département/NAF2-digit and at the département/3-digit industry are respectively introduced in columns 6 and 7. Standard errors are clustered at the 3 -digit level in columns 1 to 5 , at the département/NAF2digit level in column 6, and at the département/3-digit level in column 7 . 
Table A-4: Competitiveness clusters and export performance premium with controls (Customs + ABS)

\begin{tabular}{|c|c|c|c|c|c|c|c|}
\hline \multirow[b]{2}{*}{ Model: } & \multicolumn{7}{|c|}{ Dependent Variable: $\ln$ export value in 2004} \\
\hline & (1) & $(2)$ & $(3)$ & (4) & $(5)$ & (6) & (7) \\
\hline Best category is WCC & $\begin{array}{c}0.052 \\
(0232)\end{array}$ & $\begin{array}{c}0.047 \\
(0232)\end{array}$ & $\begin{array}{c}0.043 \\
(0232)\end{array}$ & $\begin{array}{c}0.049 \\
(0228)\end{array}$ & $\begin{array}{c}-0.111 \\
(0.217)\end{array}$ & $\begin{array}{r}0.053 \\
(0.206)\end{array}$ & $\begin{array}{c}0.033 \\
(0.206)\end{array}$ \\
\hline Best category is PWCC & 0.042 & 0.035 & 0.028 & 0.035 & -0.059 & 0.008 & -0.012 \\
\hline Best category is NCC & $\begin{array}{c}(0.222) \\
0.229^{b} \\
(0.097)\end{array}$ & $\begin{array}{c}(0.223) \\
0.226^{b} \\
(0.097)\end{array}$ & $\begin{array}{c}(0.222) \\
0.224^{b} \\
(0.097)\end{array}$ & $\begin{array}{c}(0.220) \\
0.208^{b} \\
(0.096)\end{array}$ & $\begin{array}{c}0.173^{c} \\
(0.094)\end{array}$ & $\begin{array}{c}(0.113)^{b} \\
(0.089)\end{array}$ & $\begin{array}{c}(0.212) \\
0.181^{b} \\
(0.089)\end{array}$ \\
\hline Multi-competitiveness cluster firm & $\begin{array}{l}0.441^{b} \\
(0.180)\end{array}$ & $\begin{array}{c}0.446^{b} \\
(0.180)\end{array}$ & $\begin{array}{l}0.445^{b} \\
(0.180)\end{array}$ & $\begin{array}{l}0.417^{b} \\
(0.185)\end{array}$ & $\begin{array}{l}0.370^{b} \\
(0.179)\end{array}$ & $\begin{array}{l}0.405^{b} \\
(0.168)\end{array}$ & $\begin{array}{l}0.391^{b} \\
(0.167)\end{array}$ \\
\hline Number of employees & $\begin{array}{l}1.233^{a} \\
(0.031)\end{array}$ & $\begin{array}{l}1.229^{a} \\
(0.032)\end{array}$ & $\begin{array}{l}1.223^{a} \\
(0.032)\end{array}$ & $\begin{array}{l}1.224^{a} \\
(0.032)\end{array}$ & $\begin{array}{l}1.245^{a} \\
(0.033)\end{array}$ & $\begin{array}{l}0.949^{a} \\
(0.029)\end{array}$ & $\begin{array}{c}0.939^{a} \\
(0.029)\end{array}$ \\
\hline IV total factor productivity & $\begin{array}{c}0.746^{a} \\
(0.058)\end{array}$ & $\begin{array}{c}0.746^{a} \\
(0.058)\end{array}$ & $\begin{array}{l}0.744^{a} \\
(0.058)\end{array}$ & $\begin{array}{l}0.746^{a} \\
(0.057)\end{array}$ & $\begin{array}{c}0.357^{a} \\
(0.053)\end{array}$ & $\begin{array}{l}0.256^{a} \\
(0.049)\end{array}$ & $\begin{array}{l}0.257^{a} \\
(0.049)\end{array}$ \\
\hline 1 if no. of plants $\succ 1$ & & $\begin{array}{l}-0.013 \\
(0.049)\end{array}$ & $\begin{array}{c}-0.013 \\
(0.049)\end{array}$ & $\begin{array}{c}-0.020 \\
(0.049)\end{array}$ & $\begin{array}{c}-0.023 \\
(0.049)\end{array}$ & $\begin{array}{c}-0.040 \\
(0.045)\end{array}$ & $\begin{array}{l}-0.039 \\
(0.045)\end{array}$ \\
\hline 1 if firm belongs to a group & & $\begin{array}{c}0.067 \\
(0.050)\end{array}$ & & & & & \\
\hline 1 if firm belongs to a domestic group & & & $\begin{array}{c}0.010 \\
(0.061)\end{array}$ & $\begin{array}{c}0.535^{a} \\
(0.088)\end{array}$ & $\begin{array}{c}0.589^{a} \\
(0.088)\end{array}$ & $\begin{array}{c}0.480^{a} \\
(0.086)\end{array}$ & $\begin{array}{c}0.476^{a} \\
(0.086)\end{array}$ \\
\hline 1 if firm belongs to a foreign group & & & $\begin{array}{c}0.140^{b} \\
(0.068)\end{array}$ & $\begin{array}{c}0.693^{a} \\
(0.111)\end{array}$ & $\begin{array}{c}0.764^{a} \\
(0.108)\end{array}$ & $\begin{array}{l}0.615^{a} \\
(0.102)\end{array}$ & $\begin{array}{c}0.615^{a} \\
(0.102)\end{array}$ \\
\hline $\operatorname{Ln}($ no. of domestic affiliates in the group +1 ) & & & & $\begin{array}{c}-0.365^{a} \\
(0.054)\end{array}$ & $\begin{array}{c}-0.366^{a} \\
(0.055)\end{array}$ & $\begin{array}{c}-0.339^{a} \\
(0.053)\end{array}$ & $\begin{array}{c}-0.337^{a} \\
(0.053)\end{array}$ \\
\hline $\operatorname{Ln}($ no. of foreign affiliates in the group +1 ) & & & & $\begin{array}{l}0.204^{a} \\
(0.059)\end{array}$ & $\begin{array}{l}0.154^{b} \\
(0.061)\end{array}$ & $\begin{array}{l}0.171^{a} \\
(0.056)\end{array}$ & $\begin{array}{l}0.167^{a} \\
(0.057)\end{array}$ \\
\hline Ln (Firm average wage) & & & & & $\begin{array}{l}1.714^{a} \\
(0.125)\end{array}$ & $\begin{array}{l}1.474^{a} \\
(0.101)\end{array}$ & $\begin{array}{l}1.477^{a} \\
(0.102)\end{array}$ \\
\hline Total imports of the firm & & & & & & $\begin{array}{l}0.155^{a} \\
(0.006)\end{array}$ & $\begin{array}{l}0.155^{a} \\
(0.006)\end{array}$ \\
\hline Ln (Firm subsidies) & & & & & & & $\begin{array}{l}0.010^{b} \\
(0.004)\end{array}$ \\
\hline Numb & 13510 & 13510 & 13510 & 13510 & 13499 & 13499 & 13499 \\
\hline $\mathrm{R}^{2}$ & 0.298 & 0.299 & 0.299 & 0.303 & 0.325 & 0.395 & 0.396 \\
\hline
\end{tabular}

Note: Fixed effects at the département/3-digit level are introduced in all columns. Standard errors are clustered at the département/3-digit industry level. 
Table A-5: Competitiveness clusters and export performance growth 2001-2004 (Customs and ABS)

\begin{tabular}{|c|c|c|c|c|c|c|c|}
\hline \multirow[b]{2}{*}{ Model: } & \multicolumn{7}{|c|}{ Dependent Variable: $\Delta$ Performance } \\
\hline & $\begin{array}{l}\text { Export } \\
\text { value }\end{array}$ & $\begin{array}{c}\text { Export } \\
\text { quantity }\end{array}$ & $\begin{array}{l}\text { Unit } \\
\text { value }\end{array}$ & $\begin{array}{l}\text { Number } \\
\text { products }\end{array}$ & $\begin{array}{c}\text { Number of } \\
\text { destinations }\end{array}$ & $\begin{array}{l}\text { Weighted } \\
\text { distance }\end{array}$ & TFP \\
\hline Best category is WCC & $\begin{array}{c}0.071 \\
(0.176)\end{array}$ & $\begin{array}{l}-0.224 \\
(0.222)\end{array}$ & $\begin{array}{l}0.360^{a} \\
(0.118)\end{array}$ & $\begin{array}{l}-0.027 \\
(0.109)\end{array}$ & $\begin{array}{c}0.066 \\
(0.071)\end{array}$ & $\begin{array}{c}0.010 \\
(0.086)\end{array}$ & $\begin{array}{l}-0.127^{c} \\
(0.068)\end{array}$ \\
\hline Best category is PWCC & $\begin{array}{c}0.044 \\
(0.156)\end{array}$ & $\begin{array}{c}-0.067 \\
(0.193)\end{array}$ & $\begin{array}{c}0.055 \\
(0.134)\end{array}$ & $\begin{array}{c}0.056 \\
(0.175)\end{array}$ & $\begin{array}{c}-0.031 \\
(0.111)\end{array}$ & $\begin{array}{c}0.111 \\
(0.082)\end{array}$ & $\begin{array}{c}0.139^{b} \\
(0.054)\end{array}$ \\
\hline Best category is $\mathrm{NCC}$ & $\begin{array}{l}0.195^{a} \\
(0.056)\end{array}$ & $\begin{array}{l}0.133^{c} \\
(0.070)\end{array}$ & $\begin{array}{l}0.129^{b} \\
(0.055)\end{array}$ & $\begin{array}{c}0.020 \\
(0.059)\end{array}$ & $\begin{array}{l}0.121^{b} \\
(0.052)\end{array}$ & $\begin{array}{l}-0.003 \\
(0.035)\end{array}$ & $\begin{array}{c}0.040^{b} \\
(0.018)\end{array}$ \\
\hline Multi-competitiveness cluster firm & $\begin{array}{l}0.182^{c} \\
(0.111)\end{array}$ & $\begin{array}{c}0.119 \\
(0.146)\end{array}$ & $\begin{array}{c}0.018 \\
(0.098)\end{array}$ & $\begin{array}{c}0.136 \\
(0.102)\end{array}$ & $\begin{array}{l}-0.007 \\
(0.068)\end{array}$ & $\begin{array}{l}-0.074 \\
(0.062)\end{array}$ & $\begin{array}{c}0.044 \\
(0.041)\end{array}$ \\
\hline Number of employees in 2001 & $\begin{array}{l}0.268^{a} \\
(0.022)\end{array}$ & $\begin{array}{c}0.340^{a} \\
(0.027)\end{array}$ & $\begin{array}{c}0.018 \\
(0.013)\end{array}$ & $\begin{array}{c}0.037^{c} \\
(0.019)\end{array}$ & $\begin{array}{c}0.087^{a} \\
(0.026)\end{array}$ & $\begin{array}{c}0.029^{a} \\
(0.007)\end{array}$ & $\begin{array}{c}0.023^{a} \\
(0.005)\end{array}$ \\
\hline IV total factor productivity in 2001 & $\begin{array}{l}0.267^{a} \\
(0.043)\end{array}$ & $\begin{array}{l}0.251^{a} \\
(0.051)\end{array}$ & $\begin{array}{l}0.126^{a} \\
(0.032)\end{array}$ & $\begin{array}{c}0.039 \\
(0.033)\end{array}$ & $\begin{array}{c}0.101^{b} \\
(0.040)\end{array}$ & $\begin{array}{c}0.043^{b} \\
(0.019)\end{array}$ & $\begin{array}{l}-0.325^{a} \\
(0.019)\end{array}$ \\
\hline Ln export value in 2001 & $\begin{array}{l}-0.234^{a} \\
(0.012)\end{array}$ & & & & & & \\
\hline Ln export qty in 2001 & & $\begin{array}{c}-0.246^{a} \\
(0.013)\end{array}$ & & & & & \\
\hline Ln unit value in 2001 & & & $\begin{array}{r}-0.344^{a} \\
(0.013)\end{array}$ & & & & \\
\hline No. exported products in 2001 & & & & $\begin{array}{l}-0.007^{a} \\
(0.001)\end{array}$ & & & \\
\hline No. destinations in 2001 & & & & & $\begin{array}{r}-0.014^{a} \\
(0.001)\end{array}$ & & \\
\hline Ln of weighted average distance & & & & & & $\begin{array}{r}-0.349^{a} \\
(0.011)\end{array}$ & \\
\hline Number of observations & 10812 & 10807 & 10807 & 10812 & 10812 & 10812 & 10721 \\
\hline $\mathrm{R}^{2}$ & 0.115 & 0.121 & 0.169 & 0.018 & 0.028 & 0.177 & 0.125 \\
\hline
\end{tabular}

Note: Fixed effects at the département/3-digit level are introduced in all columns. Standard errors are clustered at the département/3-digit level. 
Table A-6: Competitiveness clusters and export performance growth 2001-2004 (Customs $+\mathrm{ABS}$ )

\begin{tabular}{|c|c|c|c|c|c|c|c|}
\hline \multirow[b]{2}{*}{ Model: } & \multicolumn{7}{|c|}{ Dependent Variable: $\Delta \ln$ export } \\
\hline & (1) & $(2)$ & (3) & (4) & $(5)$ & (6) & (7) \\
\hline Best category is WCC & $\begin{array}{c}0.071 \\
(0.176)\end{array}$ & $\begin{array}{c}0.071 \\
(0.176)\end{array}$ & $\begin{array}{c}0.072 \\
(0.176)\end{array}$ & $\begin{array}{c}0.072 \\
(0.176)\end{array}$ & $\begin{array}{c}0.059 \\
(0.174)\end{array}$ & $\begin{array}{c}0.112 \\
(0.166)\end{array}$ & $\begin{array}{c}0.108 \\
(0.166)\end{array}$ \\
\hline Best category is $\mathrm{PWCC}$ & $\begin{array}{c}0.044 \\
(0.156)\end{array}$ & $\begin{array}{c}0.043 \\
(0.156)\end{array}$ & $\begin{array}{c}0.041 \\
(0.156)\end{array}$ & $\begin{array}{c}0.046 \\
(0.157)\end{array}$ & $\begin{array}{c}0.032 \\
(0.156)\end{array}$ & $\begin{array}{c}0.031 \\
(0.156)\end{array}$ & $\begin{array}{c}0.025 \\
(0.156)\end{array}$ \\
\hline Best category is $\mathrm{NCC}$ & $\begin{array}{c}0.195^{a} \\
(0.056)\end{array}$ & $\begin{array}{c}0.194^{a} \\
(0.056)\end{array}$ & $\begin{array}{l}0.194^{a} \\
(0.056)\end{array}$ & $\begin{array}{c}0.192^{a} \\
(0.056)\end{array}$ & $\begin{array}{c}0.186^{a} \\
(0.057)\end{array}$ & $\begin{array}{c}0.184^{a} \\
(0.056)\end{array}$ & $\begin{array}{c}0.182^{a} \\
(0.056)\end{array}$ \\
\hline Multi-competitiveness cluster firm & $\begin{array}{c}0.182^{c} \\
(0.111)\end{array}$ & $\begin{array}{c}0.182^{c} \\
(0.111)\end{array}$ & $\begin{array}{c}0.182^{c} \\
(0.111)\end{array}$ & $\begin{array}{c}0.175 \\
(0.112)\end{array}$ & $\begin{array}{c}0.167 \\
(0.111)\end{array}$ & $\begin{array}{c}0.183^{c} \\
(0.110)\end{array}$ & $\begin{array}{c}0.178 \\
(0.110)\end{array}$ \\
\hline Ln Number of employees in 2001 & $\begin{array}{c}0.268^{a} \\
(0.022)\end{array}$ & $\begin{array}{c}0.266^{a} \\
(0.023)\end{array}$ & $\begin{array}{l}0.263^{a} \\
(0.023)\end{array}$ & $\begin{array}{l}0.264^{a} \\
(0.023)\end{array}$ & $\begin{array}{c}0.273^{a} \\
(0.023)\end{array}$ & $\begin{array}{c}0.211^{a} \\
(0.022)\end{array}$ & $\begin{array}{c}0.208^{a} \\
(0.022)\end{array}$ \\
\hline Ln IV total factor productivity in 2001 & $\begin{array}{c}0.267^{a} \\
(0.043)\end{array}$ & $\begin{array}{c}0.266^{a} \\
(0.043)\end{array}$ & $\begin{array}{l}0.265^{a} \\
(0.043)\end{array}$ & $\begin{array}{c}0.266^{a} \\
(0.042)\end{array}$ & $\begin{array}{c}0.196^{a} \\
(0.043)\end{array}$ & $\begin{array}{c}0.169^{a} \\
(0.041)\end{array}$ & $\begin{array}{c}0.171^{a} \\
(0.041)\end{array}$ \\
\hline Ln firm exports in 2001 & $\begin{array}{c}-0.234^{a} \\
(0.012)\end{array}$ & $\begin{array}{c}-0.234^{a} \\
(0.012)\end{array}$ & $\begin{array}{c}-0.234^{a} \\
(0.012)\end{array}$ & $\begin{array}{c}-0.235^{a} \\
(0.012)\end{array}$ & $\begin{array}{c}-0.240^{a} \\
(0.012)\end{array}$ & $\begin{array}{c}-0.272^{a} \\
(0.013)\end{array}$ & $\begin{array}{r}-0.272^{a} \\
(0.013)\end{array}$ \\
\hline 1 if no. of plants $\succ 1$ & & $\begin{array}{c}0.008 \\
(0.032)\end{array}$ & $\begin{array}{c}0.008 \\
(0.032)\end{array}$ & $\begin{array}{c}0.007 \\
(0.032)\end{array}$ & $\begin{array}{c}0.006 \\
(0.032)\end{array}$ & $\begin{array}{c}0.002 \\
(0.031)\end{array}$ & $\begin{array}{c}0.002 \\
(0.031)\end{array}$ \\
\hline 1 if firm belongs to a group & & $\begin{array}{c}0.007 \\
(0.031)\end{array}$ & & & & & \\
\hline 1 if firm belongs to a domestic group & & & $\begin{array}{c}-0.014 \\
(0.038)\end{array}$ & $\begin{array}{c}0.075 \\
(0.062)\end{array}$ & $\begin{array}{c}0.090 \\
(0.061)\end{array}$ & $\begin{array}{c}0.079 \\
(0.063)\end{array}$ & $\begin{array}{c}0.077 \\
(0.063)\end{array}$ \\
\hline 1 if firm belongs to a foreign group & & & $\begin{array}{c}0.033 \\
(0.043)\end{array}$ & $\begin{array}{c}0.104 \\
(0.070)\end{array}$ & $\begin{array}{c}0.120^{c} \\
(0.070)\end{array}$ & $\begin{array}{c}0.10 \\
(0.068)\end{array}$ & $\begin{array}{c}0.10 \\
(0.068)\end{array}$ \\
\hline Ln (no. of domestic affiliates in the group +1 ) & & & & $\begin{array}{l}-0.063^{c} \\
(0.037)\end{array}$ & $\begin{array}{l}-0.068^{c} \\
(0.037)\end{array}$ & $\begin{array}{c}-0.070^{c} \\
(0.038)\end{array}$ & $\begin{array}{l}-0.069^{c} \\
(0.038)\end{array}$ \\
\hline Ln (no. of foreign affiliates in the group +1 ) & & & & $\begin{array}{c}0.045 \\
(0.043)\end{array}$ & $\begin{array}{c}0.041 \\
(0.043)\end{array}$ & $\begin{array}{c}0.052 \\
(0.042)\end{array}$ & $\begin{array}{c}0.051 \\
(0.043)\end{array}$ \\
\hline Ln (Firm average wage) & & & & & $\begin{array}{c}0.280^{a} \\
(0.077)\end{array}$ & $\begin{array}{l}0.235^{a} \\
(0.071)\end{array}$ & $\begin{array}{c}0.236^{a} \\
(0.071)\end{array}$ \\
\hline Ln firm imports & & & & & & $\begin{array}{c}0.057^{a} \\
(0.005)\end{array}$ & $\begin{array}{c}0.057^{a} \\
(0.005)\end{array}$ \\
\hline Ln firm subsidies & & & & & & & $\begin{array}{c}0.003 \\
(0.003)\end{array}$ \\
\hline Number of $\mathrm{o}$ & 10812 & 10812 & 10812 & 10812 & 10803 & 10803 & 10803 \\
\hline $\mathrm{R}^{2}$ & 0.115 & 0.115 & 0.115 & 0.116 & 0.118 & 0.143 & 0.143 \\
\hline
\end{tabular}

Note: Fixed effects at the département/3-digit level are introduced in all columns. Standard errors are clustered at the département/3-digit industry level. 